\title{
TRANSPARENCY, INVESTMENT PROTECTION AND THE ROLE OF THE EUROPEAN PARLIAMENT
}

\author{
Szilárd Gáspár-Szilágyi* \\ Postdoctoral Fellow, PluriCourts, University of Oslo
}

\begin{abstract}
This article looks at the role that the European Parliament (EP), as the only democratically elected EU institution, plays in ensuring transparency in the EU's newly concluded free trade and investment agreements (FTIAs). Using the empirically tested findings of political scientists, the article puts forward several normative claims. First, the EP should ensure that the FTIAs provide high levels of participatory transparency that allows members of the 'public' to actively observe and take part in the international decision-making process. Second, if the participation of members of the general public is not feasible, then at least certain members of the EP should be able to observe the international decision-making process and submit observations. Third, if a deliberative democratic ideal is difficult to reach, legitimacy can still be guaranteed by providing public access to the reasons for taking an international decision, after the decision has been taken. In light of these normative claims, the article discusses the transparency provisions the EP should ensure are included in the parts of the FTIAs that deal with the proceedings of the Investment Courts (ICs), the workings of treaty committees handling investment protection and the selection of arbitrator judges for the ICs. Proposals are also made for how the EP should achieve these.
\end{abstract}

\section{Keywords: Free Trade Agreements; Investment Protection; Transparency; European Parliament;}




\section{Contents}

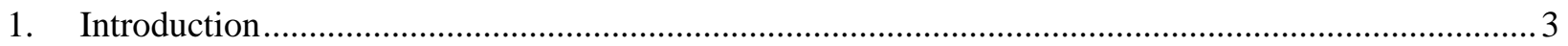

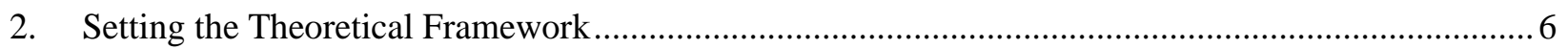

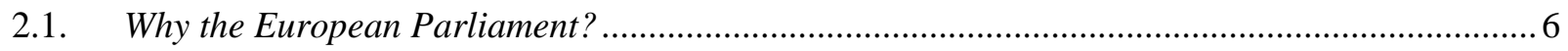

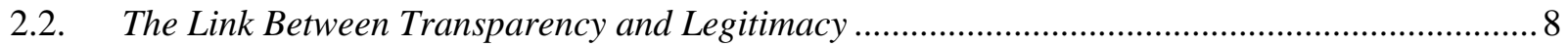

2.3. Several Understandings of Transparency .......................................................................... 9

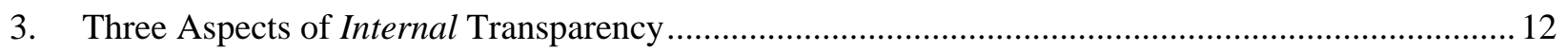

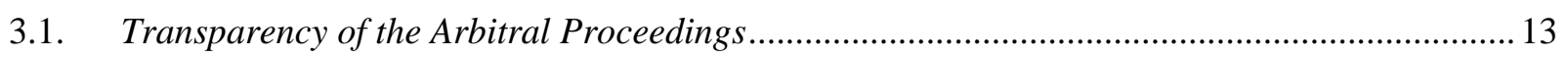

3.1.1. The Current Situation: Quite Developed Rules .............................................................. 13

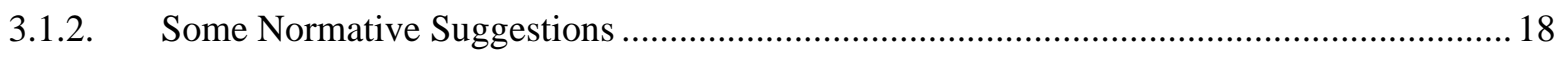

3.1.3. The EP Putting Forward Tailor-Made Solutions ............................................................ 21

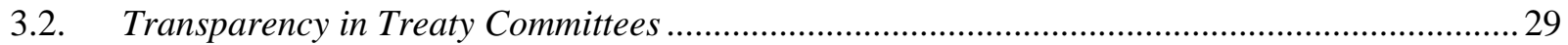

3.2.1. Extensive Powers of Interpretation, but No Transparency?.............................................29

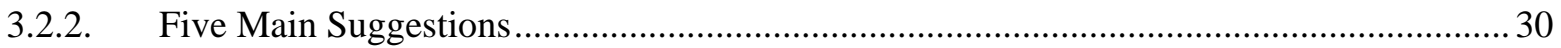

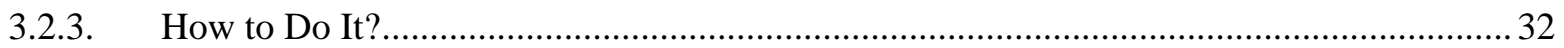

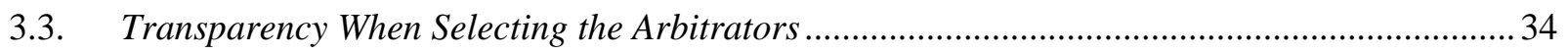

3.3.1. A More Robust System, but What about Transparency? ................................................ 35

3.3.2. Differentiated Normative Suggestions. Who Are the Addressees?.................................. 36

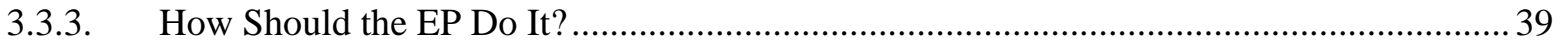

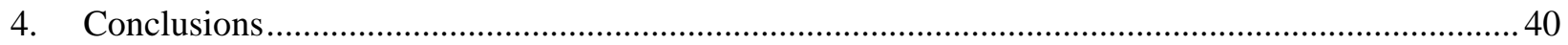




\section{Introduction}

The EU's more recent presence in the field of international investment law following the Lisbon amendments, and its eagerness to tackle some of the issues that undermine the credibility of international investment protection, ${ }^{1}$ poses various challenges. On the one hand, the EU is striving to keep its position as an international rule-maker in the field of international trade and to become an international norm setter in the field of international investment. ${ }^{2}$ On the other hand, the quest to remain/become an international norm-setter might not always coincide with the wishes of parts of the EU electorate. One just has to look at the 2015 anti-TTIP protests in Berlin, ${ }^{3}$ the open letter of over a hundred law professors against investor-state dispute settlement (ISDS) under the proposed Transatlantic Trade and Investment Partnership (TTIP), ${ }^{4}$ the rejection of ISDS by civil society during the EU Commission's 2015 public consultation ${ }^{5}$ or the recent attempted 'sabotage' of the signature of The Comprehensive Economic and Trade Agreement between the EU and Canada (CETA) by the regional parliament of Wallonia. ${ }^{6}$

As Putman has famously argued, the negotiation of an international agreement is a two-level game during which the negotiator needs to take into consideration the wishes of the other contracting party, as well as to consider the domestic concerns in one's home state. ${ }^{7}$ In case of

* This work was partly supported by the Research Council of Norway through its Centres of Excellence funding scheme, project number 223274. I would like to thank Geir Ulfstein (Oslo), Taylor St John (Oslo), Jed Odermatt (Copenhagen) and Güneș Ünüvar (Copenhagen) for their constructive comments, as well as the organizers and participants of the 'The Role of the European Parliament in the Conclusion and Implementation of International Agreements on International Economic Law Issues' (Dec 2016) conference and the iCourts-PluriCourts joint workshop (Feb 2017).

1 EU Commission, 'Investment in TTIP and Beyond - The Path to Reform' (Concept Paper 2015) <https://goo.gl/KXFzYv> accessed 3 April 2017.

2 see Daniel S Hamilton and Jacques Pelkmans (eds), Rule-Makers or Rule-Takers (Rowman \& Littlefield International 2015).

${ }^{3}$ The idea of ISDS was met with protests all around Europe, most importantly the massive rally in Berlin which gathered 250.000 people. See Chris Johnston, 'Berlin anti-TTIP Trade Deal Protest Attracts Hundreds of Thousands', The Guardian (Berlin 10 October 2015) <goo.gl/oTKmHd> accessed 3 April 2017.

4 'Legal Statement on Investment Protection and Investor-State Dispute Settlement Mechanisms in TTIP and CETA', October $2016<$ <oo.gl/nIXCcs> accessed 3 April 2017.

${ }^{5}$ European Commission, 'Online Public Consultation on Investment Protection and Investor-to-State Dispute Settlement (ISDS) in the Transatlantic Trade and Investment Partnership (TTIP)', SWD (2015) 3 final <goo.gl/dfYpME> accessed 3 April 2017.

${ }^{6}$ Simon Marks and Christian Oliver, 'Belgium's Wallons cave on EU-Canada Trade Deal', Politico (27 October 2016) <goo.g1/5loNb5> accessed 3 April 2017.

${ }^{7}$ Robert D Putman, 'Diplomacy and Domestic Politics: The Logic of Two-Level Games' (1988) 42(3) International Organization 427. 
the EU one can refer to a multi-level game, in which the EU negotiator (the Commission) ${ }^{8}$ has to satisfy multiple actors: the other contracting party(ies), various domestic constituencies, the other EU level institutions, as well as Member State and regional institutions. ${ }^{9}$

The EU's evolving investment policy is a good example of this multi-level game. The last six years of EU investment policy have mainly been a reactive process during which an initially fairly inert Commission ${ }^{10}$ had to tackle the concerns raised by the European Parliament, ${ }^{11}$ national parliaments, ${ }^{12}$ by civil society, NGOs, ${ }^{13}$ businesses and even the public at large. The pressure put on the EU negotiator by the European Parliament (EP) and national parliaments is understandable given the disconnect between the EU citizens and the corporate world, the rising backlash against globalization, as well as the increased amount of decision-making happening in the international arena, which is often not transparent and over which 'domestic' ${ }^{14}$ parliaments often have no proper oversight. ${ }^{15}$

In light of the above, this paper focuses on the role that the EP plays in the negotiation, conclusion and implementation of free trade and investment agreements (FTIAs). Due to the broad nature of the topic, the research framework is delimited in the following way. First, I focus on the $E P$, as the only democratically elected EU institution meant to represent the interests of

${ }^{8}$ arts 207(3), 218(3) and 218(9) Treaty on the Functioning of the European Union (TFEU) [2012] OJ C 326/47. On the EU's international representation see Frank Hoffmeister, 'The European Union and the Peaceful Settlement of International Disputes' (2012) Chinese Journal of International Law 77; Jan Wouters et al, 'The EU in the Worlds of International Organizations: Diplomatic Aspirations, Legal Hurdles and Political Realities' (2013) Working Paper No.121, Leuven Centre for Global Governance Studies; From the Board, 'Litigation on External Relations Powers after Lisbon: The Member States Reject Their Own Treaty’ (2016) 43(1) LIEI 1. Art 18(2) Consolidated Version of the Treaty on the European Union (TEU) [2012] OJ C 326/01. In the case of the Common Foreign and Security Policy (CFSP) and Common Security and Defence Policy (SDP) the High Representative provides the EU's representation.

9 Davor Jančić, 'TTIP and Legislative-Executive Relations in EU Trade Policy' (2017) 40(1) West European Politics 202, 205.

${ }^{10}$ Christian J Tams, 'Procedural Aspects of Investor-State Dispute Settlement: The Emergence of a European Approach' (2014) 15 JWIT 585, 587. See art 218(3) TFEU.

${ }^{11}$ see European Parliament, 'Resolution of 8 July 2015 containing the European Parliament's recommendations to the European Commission on the negotiations for the Transatlantic Trade and Investment Partnership (TTIP)' A8-0175/2015.

12 Jančić 2017 (n 9) 213-215.

13 'Joint Analysis of CETA's Investment Court System' (A joint briefing by several NGOs June 2016) $<$ goo.gl/jx5qcK>; Client Earth, 'Legality of Investor-State Dispute Settlement (ISDS) under EU Law' (Legal Analysis 22 October 2015) <goo.gl/S19vKo>; Corporate Europe, 'The Zombie ISDS' (March 2016) <goo.gl/Hjdis3> all accessed 3 April 2017.

${ }^{14}$ In this paper I use a broad understanding of 'domestic' that includes both EU and Member State level institutions. This is so because the EU also represents its own autonomous, constitutional legal order, separate from international law. See C-26/62 Van Gend den Loos EU:C:1963:1, p 12.

${ }^{15}$ Davor Jančić, 'The Role of the European Parliament and the US Congress in Shaping Transatlantic Relations: TTIP, NSA Surveillance, and CIA Renditions' (2016) 54(4) JCMS 896, 900-901. 
the 'EU electorate'. ${ }^{16}$ The role of Member State parliaments is not covered due to the focus of this special issue on the EP and the recent lack of clarity as to whether the FTIAs will be concluded as sole EU agreements or as 'mixed' agreement, together with the Member States. ${ }^{17}$ Furthermore, the role of national parliaments has also been the focus of recent academic work. ${ }^{18}$ Second, the central theme of the article is the way in which the EP can ensure that various international bodies set up by recent FTIAs work in a transparent manner. Third, given the multitude of policy areas covered by FTIAs, ${ }^{19}$ the research focuses on the need to ensure transparency in FTIA provisions that cover investment protection. Fourth, the article does not address in detail the issues surrounding secrecy and whistle-blowers. ${ }^{20}$

The theoretical framework and terms used in this research are set out in Part 2 and draw from Political Science and Legal Theory. It is argued that both transparency in process and transparency in rationale can contribute to the public legitimacy ${ }^{21}$ of the international decision-making processes. The recent FTIAs provide for the setting up of various international bodies, such as treaty committees and investor-state 'courts', ${ }^{22}$ whose decisions can have a profound impact on investors, the public purse, and the interpretation of the agreements. Given the general public's suspicion towards the investment chapters of recent FTIAs, especially ISDS, ${ }^{23}$ increasing the transparency of the decision-making process of the afore-mentioned bodies might lead to their greater public acceptance and thus, greater public legitimacy. Following the Lisbon Treaty's efforts to reinforce representative democracy, ${ }^{24}$ the EP should strive to address the legitimacy concerns voiced by part of the EU electorate, by ensuring greater

\footnotetext{
16 art 10(2) TEU; art 223(1) TFEU. On representation see Nadia Urbinati and Mark Warren, 'The Concept of Representation in Contemporary Democratic Theory’ (2008) 11 Annual Review of Political Science 387.

17 Opinion A-2/15, EU-Singapore FTA, pending.

18 see Jančić 2017 (n 9).

19 For example trade barriers, intellectual property, services, investment, labour standards, data protection, environmental protection, etc.

${ }^{20}$ see Vigjilenca Abazi, ‘European Parliamentary Oversight Behind Closed Doors’ (2016) 5(1) CJICL 31.

${ }^{21}$ Jenny de Fine Licht and Daniel Naurin, 'Open Decision-Making Procedures and Public Legitimacy' in Jon Elster (ed), Secrecy and Publicity in Votes and Debates (CUP 2015).

22 The EU is introducing so called two-tier 'Investment Courts'.

${ }^{23}$ See Public Consultation on TTIP (n 5).

24 The CJEU also held on several occasions that the EP's participation in the legislative process is the reflection, at EU level, 'of a fundamental democratic principle that the people should participate in the exercise of power through the intermediary of a representative assembly'. See Case 138/79 Roquette Frères v Council EU:C:1980:249, para 33; C-130/10 Parliament v Council EU:C:2012:472, para 81; Case C-263/14 Parliament v Council (Tanzania Transfer) EU:C:2016:435, para 70.
} 
parliamentary oversight and involvement during the negotiation, conclusion, and implementation of international agreements. ${ }^{25}$

Based on the theoretical discussion, this article will propose a set of concrete transparency provisions in Part 3 that the EP should ensure are included in the investment chapters of recent FTIAs. More specifically, transparency in the following cases is discussed: the investor-state arbitral/court proceedings, the workings of treaty committees dealing with investment protection, and the selection of the arbitrator-judges. Once I map out what should be included, I propose guidelines for the EP on how to ensure the inclusion of such transparency provisions.

There are two main reasons why this research is important. First, following the recent public backlash against ISDS in TTIP and CETA, the conclusion of FTIAs by the EU is on shaky grounds. Therefore, finding ways of increasing the public legitimacy of these mega-regionals is crucial if the EU is to have a working common commercial policy. Second, if we want to make sure that the EU remains an international norm setter, then first some of the public legitimacy concerns surrounding FTIAs must be addressed.

\section{Setting the Theoretical Framework}

\subsection{Why the European Parliament?}

The organizers of the 'Role of the European Parliament in the Conclusion and Implementation of International Agreements on International Economic Law Issues' Conference (Dec 9, 2016) chose the role of the European Parliament as the central theme of the conference. Nevertheless, there are other reasons why more academic work on the role of the EP in EU external relations is needed.

First, the role of the EP in shaping the EU's investment policy cannot be underestimated. The EP directly represents the EU citizens at EU level ${ }^{26}$ and is the only EU institution that is elected by direct universal suffrage. ${ }^{27}$ Whilst it is true that in a representative democracy ${ }^{28}$ the

\footnotetext{
${ }^{25}$ see Juan Mayoral, 'Democratic Improvements in the European Union under the Lisbon Treaty. Institutional Changes Regarding Democratic Government in the EU' (2011) EUI Working Paper <goo.gl/qMIVx0> accessed 3 April 2017.

${ }^{26}$ art $10(2)$ TEU.

${ }^{27}$ art 223(1) TFEU.

${ }^{28}$ art 10(2) TEU.
} 
representatives do not simply act as a proxy of the citizens, but may also adopt their own positions, the representatives should safeguard the will or interests of the citizens. ${ }^{29}$ This is reflected, for example, by the pressure the EP exerted on the EU Commission in order to address some of the public legitimacy concerns affecting the EU's investment policy. ${ }^{30}$

Second, the Lisbon amendments sought to reinforce both representative and participatory democracy in the EU. ${ }^{31}$ For example, internally the EP became co-legislator, ${ }^{32}$ while externally the role of the EP in the negotiation, conclusion and implementation of international agreements has been increased. Article 218(6)(a)v TFEU now requires the consent of the EP for international agreements that cover fields for which the ordinary legislative procedure is required. This means that for the conclusion of FTIAs, the EP has the power to veto the agreements. ${ }^{33}$ This is not just a theoretical possibility, as evidenced by the EP's veto of the ACTA in 2012 or the initial rejection of the SWIFT Interim Agreement in 2010. ${ }^{34}$ Under Article 218(10) TFEU the EP also possesses a formal right to be 'informed' 'immediately and fully' at all stages of the conclusion of an international agreement. According to the CJEU, the EP's right to be informed under Article 218(10) TFEU constitutes and essential procedural requirement the breach of which results in the annulment of the Council decision concluding the international agreement. ${ }^{35}$ Furthermore, Article 218(11) TFEU gives the power to the EP (and the other major institutions and Member States) to ask the CJEU for an opinion on the compatibility of the proposed agreement with the EU legal order. For e.g. at the end of November 2016 the EP surprisingly voted not to ask for a CJEU opinion on the compatibility of the CETA ISDS provisions with EU law. ${ }^{36}$ Nevertheless, even with the post-Lisbon improvements, the powers of the various EU institutions in external affairs are not fully settled and the CJEU is increasingly faced with cases

${ }^{29}$ see Mark Bevir, Encyclopedia of Political Theory - Representative Democracy (SAGE 2010).

${ }^{30}$ see European Parliament, 'Resolution of 8 July 2015' (n 11).

${ }^{31}$ Mayoral (n 25)

32 art 224 TFEU.

${ }^{33}$ For an overview see European Parliament, 'EPLO Brief: The role of the European Parliament on International Trade' (2015) <goo.gl/JxhPx9> accessed 3 April 2017.

${ }^{34}$ Ariadna R Servent, 'The Role of the European Parliament in International Negotiations after Lisbon' (2014) 21(4) Journal of European Public Policy 568, 574. The EP does not necessarily have to veto an agreement. It can also postpone its consent until the agreement is renegotiated, such as in the case of the Passengers Name Record (PNR) agreement.

${ }^{35}$ Case C-658/11 Parliament v Council (Mauritius Transfer) EU:C:2014:2025, para. 86; Tanzania Transfer (n 24) para 84.

${ }^{36}$ EU Observer, 'MEPs Reject Court Referral for CETA' (23 Nov 2016) <https://euobserver.com/tickers/136007> accessed 3 April 2017. 
concerning inter-institutional power struggles in this field. ${ }^{37}$ Therefore, it is paramount to understand how the EP can increase its oversight over the conclusion and implementation of FTIAs via both formal and informal means.

Third, the EU itself is a system of multi-level governance where decisions are taken both at Member State and at EU level. The levels of decision-making, however, do not end here. International agreements concluded by the EU create their own international institutions, bodies, adjudicative forums, with decision-making power. The works of such bodies are often not fully known to the representative domestic bodies, such as the EP, yet alone the electorate. Therefore, it is argued that in an effort to bring international decision-making closer to the EU citizen, the EP's oversight of the workings of international bodies must be thoroughly discussed, and if possible, improved.

\subsection{The Link Between Transparency and Legitimacy}

'Legitimacy' is a vague concept surrounded by 'fuzziness and indeterminacy'. ${ }^{38}$ Legal philosophers, theorists and political scientists have come up with multiple classifications of legitimacy, encompassing terms such as legal, moral and social legitimacy, ${ }^{39}$ perceived legitimacy, ${ }^{40}$ or public ${ }^{41}$ and democratic legitimacy. ${ }^{42}$ In this paper I rely on the concept of 'legitimacy/public legitimacy' in the sense of a belief of the public that the appointed decision-makers have the right to make decisions. ${ }^{43}$ In other words, 'legitimacy' in this article refers to the perception of the EU citizens of whether the various bodies set up by the recent FTIAs, such as treaty committees and arbitral tribunals, have the right to make decisions.

37 see C-660/13 Council v Commission EU:C:2016:616; Case C-73/14 Council v Commission (ITLOS) EU:C:2015:663.

38 James Crawford, 'The Problems of Legitimacy-Speak' (2004) 98 Proceedings of the Annual ASIL Meeting 271, 271.

${ }^{39}$ Christopher A Thomas, 'The Uses and Abuses of Legitimacy in International Law' (2014) 34(4) OJIS 729, 735.

${ }^{40}$ Nienke Grossman, 'Legitimacy and International Adjudicative Bodies' (2010) 41 Geo Wash Int'l L. Rev 107, 115.

${ }^{41}$ Erik Voeten, 'Public Opinion and the Legitimacy of International Courts' (2013) 14(2) Theoretical Inquiries in Law 411.

${ }^{42}$ Andreas von Staden, 'The Democratic Legitimacy of Judicial Review Beyond the State: Normative Subsidiarity and Judicial Standards of Review' (2012) 10 IJCL 1023; Armin von Bogdandy and Ingo Venzke, 'In Whose Name? A Public Law Theory of International Adjudication' (OUP 2014) Chapter 4; Ingo Wenzke, 'Investor-State Dispute Settlement in TTIP from the Perspective of a Public Law Theory of International Adjudication' (2016) 17 JWIT $374,386$.

${ }^{43}$ De Fine Licht \& Naurin 2015 (n 21). 
The next step is to identify mechanisms through which public legitimacy can be increased. For this paper I shall rely on the empirically tested findings of Naurin, De Fine Licht and others, ${ }^{44}$ according to which a strong link exists between the legitimacy of a decision-making process and transparency vis-à-vis the public. The researchers tested two major types of transparency: several forms of transparency in process or 'fishbowl transparency', when the public has access to how a decision is made, and transparency in rationale or retrospect, when following the decision-making process, the public is given an explanation on why a decision was taken. The study concluded that 'relatively modest transparency reforms - transparency in rationale - may contribute to similar degrees of added legitimacy as more far-reaching transparency in process measures'. ${ }^{45}$ Only when transparency displays behaviour 'close to a deliberative democratic ideal, will full openness of the process improve on closed-door decisionmaking with post-decision motivations'. ${ }^{46}$ It must also be mentioned that transparency can have certain disadvantages, such as a prolongation of the arbitral process and increased costs for ensuring transparency. Furthermore, transparency might also lead to a decrease in the legitimacy of the system in the eyes of the public if they 'do not like what is revealed' ${ }^{47}$

Based on these findings and discussions, normative proposals are made later on.

\subsection{Several Understandings of Transparency}

Similarly to 'legitimacy', 'transparency' is also a wide notion. In the previous Section the concepts of transparency in process and transparency in rationale were used. A similar, somewhat interchangeable, set of terms refers to transparency in the sense of public access to and availability of information regarding the decision-making process or public participation in the decision-making process. ${ }^{48}$ These terms have a temporal aspect to them and depend on when in

\footnotetext{
${ }^{44}$ Jenny de Fine Licht and Daniel Naurin, et al, 'Does Transparency Generate Legitimacy? An Experimental Study of Procedure Acceptance of Open- and Close-Door Decision-Making' (2011) QoG Working Paper 2011:8 <goo.gl/wtyxL2> accessed 3 April 2017.

45 ibid 21.

46 ibid.

${ }^{47}$ On the advantages and disadvantages of transparency, see Noah Rubins, 'Opening the Investment Arbitration Process: At What Costs, for What Benefit?' (2006) 3(3) TSM 1; Cristoffer N Mollestad, 'See No Evil? Procedural Transparency in International Investment Law and Dispute Settlement' (2014) PluriCourts Research Paper No 14 20, 13-14 <https://goo.gl/utoSQm> accessed 3 April 2017.

${ }^{48}$ N Jansen Calamita, 'Dispute Settlement Transparency in Europe's Evolving Investment Treaty Policy' (2014) 15 JWIT 645, 649.
} 
time, relative to the decision-making process, the public could avail itself of the transparency mechanisms.

For the purposes of this discussion there is also a spatial aspect of transparency, dependent on where the decision is being made relative to the EU FTIAs. First, some decisions concerning FTIAs are made by bodies external to the agreement, such as the EP and the Council of the EU, that have decision-making powers over the agreements' 'existence'. Thus, there is a level of external transparency that is concerned with decisions taken by these external bodies, such as transparency during the agreements' negotiation, ratification or implementation. The potential of overlap between external transparency and parliamentary 'oversight' is fairly high. ${ }^{49}$ Second, some decisions concerning FTIAs will be made by bodies that are set up internally by these agreements, such as investor-state tribunals or treaty committees. Therefore, there is a level of internal transparency that is concerned with how these treaty bodies make decisions.

This article will mainly focus on aspects of internal transparency that relate to matters of investment protection. External transparency mechanisms will be examined when discussing the various ways in which the EP can influence provisions that concern internal transparency. In light of this, two major questions are asked: (a) what types of transparency provisions should the EP ensure are included in the investment chapters of recent FTIAs, and (b) how can the EP influence such transparency provisions?

As to the first question, internal transparency is examined with regard to the following: the ISDS proceedings, the workings of treaty committees dealing with investment protection, and the selection of the arbitrator-judges. Transparency of the ISDS proceedings is commonly found in discussions surrounding the legitimacy of investment protection and ISDS,${ }^{50}$ while transparency of the workings of treaty committees dealing with investment matters is a mostly neglected topic in academia. ${ }^{51}$ The powers of such committees over the implementation and interpretation of the FTIAs are quite broad. ${ }^{52}$ However, the input of the EP is not readily apparent, as the position of

\footnotetext{
${ }^{49}$ see Abazi (n 20).

${ }^{50}$ see OECD, 'Transparency and Third Party Participation in Investor-Sate Dispute Settlement Procedures' (2005) OECD Working Papers on International Investment 2005/01 <goo.gl/OfS6OJ> accessed 3 April 2017; DG Trade, 'European Commission Pushes for Full Transparency in ISDS in Current Investment Treaties' (Brussels 29 January 2015) <goo.gl/oG6BTu> accessed 3 April 2017; United Nations Convention on Transparency in Treaty-based Investor-State Arbitration (Mauritius Convention on Transparency); Calamita (n 48).

51 Szilárd Gáspár-Szilágyi, 'Binding Committee Interpretations in the EU's New Free Trade and Investment Agreements' (2017) EILAR (forthcoming).

${ }^{52}$ see Gabrielle Kaufmann-Kohler, 'Interpretive Powers of the Free Trade Commission and the Rule of Law' in Emmanuel Gaillard and Frédéric Bachand (eds), Fifteen Years of NAFTA Chapter 11 Arbitration (JurisNet 2011).
} 
the EU in treaty bodies is mainly ensured by the EU 'executive'. ${ }^{53}$ Transparency is also vital in the selection of the arbitrators/judges who shall be appointed to sit on the investment tribunals and their appellate bodies. ${ }^{54}$ This topic needs increased attention due to the EU's push to set up standing investment courts, instead of ad hoc arbitration.

Concerning the second question, the article touches upon issues of external transparency, as well as the various formal and informal tools the EP has at its disposal to increase transparency in four different phases of an international agreement's existence: the agenda setting, the negotiation, the ratification and the implementation phase.

In order to have a complete overview, two further aspects of transparency also need to be considered. One first needs to identify the subject matter of transparency (in respect of what?). When discussing the transparency of international investment law (IIL) Maupin identifies several categories of information depending on their availability and accessibility. First, some information is generally available to the public, such as the text of most investment agreements. Second, some information is more difficult to obtain and requires extra efforts and research, such as knowing the average costs of arbitration. Third, there is information, such as trade secrets, that the public should not know but also information to which the public often has no access to, such as how investor-state arbitral proceedings are conducted. ${ }^{55}$ As other authors have argued in the EU context, some sensitive information is only available to individual MEPs or the Presidents of Parliamentary Committees. ${ }^{56}$

Once the subject matter is defined, one also has to consider the intended addressees of transparency (vis-à-vis whom?). Various groups constitute the 'public' and they 'are likely to have different levels of interest in the various aspects of transparent proceedings. ${ }^{57}$ In our case, due to the complexities of multi-level governance, the 'public' interested in the transparency of international investment decision-making will be comprised of several groups: the investment law epistemic community (arbitrators, lawyers and academics), the stakeholders involved in

\footnotetext{
${ }^{53}$ For example art 218(9) TFEU, art 2001(1) NAFTA.

${ }^{54}$ The EU is pushing for two-tier investment courts in its recent FTIAs, with a possibility of setting up a multilateral Investment Court in the future. Whilst this solution has been accepted by Canada and Vietnam, it is uncertain whether the US will accept if the TTIP negotiations resume.

${ }^{55}$ Julie Maupin, 'Transparency in International Investment Law: The Good, the Bad, and the Murky' in Andrea Bianchi and Anne Peters (eds), Transparency in International Law (CUP 2013).

${ }^{56}$ See Abazi (n 20).

${ }^{57}$ Esmé Shirlow, 'Dawn of a New Era? The UNCITRAL Rules and UN Convention on Transparency in Treaty-Based Investor-State Arbitration’ (2016) 31(3) ICSID Review 622, 653. See also Mollestad (n 47) 7-12.
} 
investment disputes (states, investors, NGOs, representatives of civil society), the general public, as well as Member States and EU institutions, such as the EP or its members.

\subsection{The Normative Claims}

Now that the theoretical framework is set, the following normative claims shall be made. It is first argued that the legitimacy of the investment chapters of EU FTIAs can be strengthened if the European Parliament ensures that within the agreements, the decision-making process of bodies set up by these agreements is made (more) transparent. (a) The optimal situation would be if the EP can ensure that the FTIAs provide high levels of participatory transparency that allows members of the 'public' to actively observe and take part in the international decision-making process, for e.g. by participating as observers or/and by being able to submit amicus briefs. (b) If the participation of members of the general public is not feasible, then at least certain Members of the EP (MEPs) should be able to observe the international decision-making process and submit observations. Nonetheless, if a deliberative democratic ideal is difficult to reach, legitimacy can still guaranteed by (c) providing public access to the reasons for taking an international decision, after the decision has been taken. In other words, a basic requirement should be to make the information surrounding international decision-making available to the public.

\section{Three Aspects of Internal Transparency}

In the last decade or so, international investment law (IIL) has received a lot of backlash, ${ }^{58}$ one of the criticisms being that the IIL 'system' is not transparent enough. The following sections will address transparency in EU FTIAs with regard to the ISDS proceedings, the operation of treaty committees that deal with investment issues, and the selection of arbitrator-judges. In all three cases the following issues are discussed: What is the current situation in EU FTIAs? What needs to be changed? How should the EP influence the change?

\footnotetext{
${ }^{58}$ See Malcolm Langford, Daniel Behn and Ole Kristian Fauchald, 'Tempest in a Teapot? The International Investment Regime and State Backlash' in Thomas Gammeltoft-Hansen and Tanja E Aalberts (eds), The Changing Practices of International Law: Sovereignty, Law and Politics in a Globalising World (CUP 2016).
} 


\subsection{Transparency of the Arbitral Proceedings}

In its recent FTIAs the EU is pushing for the set-up of an Investment Court System (ICS) that would replace ad hoc investor-state dispute settlement. It needs to be mentioned tough that each bilateral FTIA would set up its own ICS, composed of an Investment Tribunal/Tribunal of First Instance and an Appellate/Appeals Tribunal. The creation of a multilateral investment court is only envisaged by these agreements. ${ }^{59}$

The current investment courts are based on the ICS model presented by the EU Commission in November 2015 prior to the $12^{\text {th }}$ round of TTIP negotiations. ${ }^{60}$ As a result of the new model, CETA's original ISDS system from 2014 was re-negotiated in early 2016. The TTIP model also found its way into EU-Vietnam and recently the EU is seeking to re-negotiate the ISDS provisions in EU-Singapore in order to follow the TTIP ICS model. ${ }^{61}$ The solutions put forward in the following sections also need to take into consideration the specifics of the FTIAs.

\subsubsection{The Current Situation: Quite Developed Rules}

Increasing transparency of the investor-state arbitral proceedings may have multiple benefits, such as promoting good governance in the host state, providing information on the conduct of multinationals, increased regulatory predictability and promoting the legitimacy of ISDS. ${ }^{62}$ Calamita provides a thorough overview up until 2014 of how the EU's push for more transparency in ISDS fits into global trends. ${ }^{63}$ Most of the over 1200 existing international investment agreements (IIAs) concluded by EU Member States, and other IIAS concluded by third-countries, are silent on matters of transparency. Nonetheless, the global trend for more recent IIAs, starting with the 1994 NAFTA, the 2004/2012 US Model BITs, the Canadian Model BIT, the CAFTA, the 2013 UNCITRAL TR ${ }^{64}$ or the recently adopted Mauritius Convention, ${ }^{65}$ is

\footnotetext{
${ }^{59}$ CETA, art 8.9; EU-Vietnam, Ch II, art 15; TTIP Proposal, Sec 3, art 12.

${ }^{60}$ European Commission, 'The Twelfth Round of Negotiations for TTIP' (March 2016) <https://goo.gl/2Cx7zH> accessed 1 April 2017.

${ }^{61}$ see Hans von der Burchard, 'EU Makes Big Step Toward Setting Investor Court as Global Norm' (Bilaterals, 7 February 2017) <goo.gl/Ppe8wC> accessed 3 April 2017.

${ }^{62}$ Calamita (n 48) 648-652.

63 ibid.

${ }^{64}$ ibid Part 4.

${ }^{65}$ EU-Singapore, art 9.30 gives the Committee on Trade in Services, Investment and Government Procurement the task to examine whether the creation of an appellate mechanism is feasible.
} 
to increase the transparency of ISDS. ${ }^{66}$ This is pursued by providing not just information to the public, such as the publication of arbitral awards, but also by providing a means for third parties to participate in the dispute-settlement proceedings via amicus briefs.

The EU Commission decided to join this growing trend and was an active participant in the UNCITRAL working groups that preceded the adoption of the 2013 Transparency Rules. The Commission's strong stance on transparency, however, has to be seen and understood in light of the growing powers of the EP in the CCP area, and the power of the EP to veto the conclusion of international trade and investment agreements. ${ }^{67}$ The need to please the co-legislator is a strong incentive to improve the standards of transparency in the FTIAs. Nonetheless, the EP's and the Commission's stance is in sharp contrast with the silence of the Council and the opposition of some Member States. ${ }^{68}$ It is quite telling that since 17 March 2015, when the Mauritius Convention opened for signature, only two states out of the three (!) needed for the Convention to enter into force have actually ratified it, Canada and Mauritius respectively. Unfortunately, none of the EU Member States have yet to ratify it, and only nine of them ${ }^{69}$ out of the current 28 , have actually signed it. ${ }^{70}$

One could speculate on why such a small number of EU states have signed it and why none of them have ratified it. One possible explanation could be that ratification is a domestic bureaucratic process that can take several years and the Convention has only been open for signature for two years. This explanation, however, might account for a lack of ratification, but not for the lack of signature from 19 EU Member States. ${ }^{71}$ Another, more general explanation could be that authoritarian states might favour confidentiality over transparency, while liberal states that have an interest in defending the investment arbitration system before their citizens might want to increase transparency, ${ }^{72}$ 'as such disputes raise legitimacy and democracy issues deserving public discussion'. ${ }^{73}$ This could explain why a country such as Germany that has faced stiff resistance against ISDS by its citizens, has signed it. Even so, EU states cannot be classified

\footnotetext{
${ }^{66}$ see Shirlow (n 57) 625-626.

${ }^{67}$ Calamita(n 48) 673-675

68 ibid.

${ }^{69}$ These are Belgium, Finland, France, Germany, Italy, Luxembourg, Netherlands, Sweden, and the UK.

70 UNCITRAL, 'Status. UN Convention on Transparency in Treaty-based Investor-State Arbitration' <https://goo.gl/pyuuUP> accessed 3 April 2017.

${ }^{71}$ One possible explanation could also be that UNCITRAL is not actively going around the world reminding states to sign and ratify the Convention.

${ }^{72}$ I thank Taylor St John for discussing this possibility.

${ }^{73}$ Mollestad (n 47) 10.
} 
as authoritarian, even though most have still not signed the Convention. A more plausible explanation is that for most states transparency comes with certain drawbacks: they might want to avoid negative publicity in case they have not treated an investor fairly; they might also fear that a public discussion might lead to an escalation of the dispute that otherwise could be solved with a confidential settlement; or more transparent proceedings might complicate and prolong the arbitral process. ${ }^{74}$ In conclusion, the main drivers behind the transparency of ISDS in EU FTIAs are the European Parliament with the Commission, and not the Member States.

Turning back to the provisions of EU FTIAs, all of them, with the exception of EU-Singapore, provide for standing investment tribunals with an appellate body. The investor can submit a claim to the tribunals if the dispute could not be resolved through consultations. ${ }^{75}$ The claim can be submitted under various arbitration rules, such as the ICSID Arbitration Rules (AR), the ICSID Additional Facility Rules (AFR), the UNCITRAL Arbitration Rules (AR) and any other rules agreed by the disputing parties. ${ }^{76}$ To various degrees, these arbitration rules might or might not include some provisions on transparency. ${ }^{77}$ Nevertheless, unlike most existing IIAs, the recent FTIAs also provide fairly extensive transparency rules, both with regard to transparency in process/participation and transparency in rationale/access to information.

The first category of information that the contracting parties need to make publicly available, mainly concerns the investors, and is only included in the text of CETA. According to Article 8.23(2) CETA, each party shall ensure that the place of delivery of notices of arbitration and other documents the investors have to submit are publicly available.

With the exception of EU-Singapore, all the other FTIAs also provide that any disputing party that benefits from third party funding has to disclose the name and address of the funder to the other disputing party and the tribunal. ${ }^{78}$ This provision, however, does not oblige the third party funded disputing party to disclose the information to the general public or to disclose the amount of the funding.

Each FTIA also includes a general provision on the transparency of the proceedings, including not just investor-state arbitration, but also the consultation phase. CETA, EU-Vietnam

\footnotetext{
${ }^{74}$ Mollestad (n 47) 8.

${ }^{75}$ CETA, art 8.23(1); EU-Singapore, art 9.15(1); EU-Vietnam, Ch II, Sec 3, art 7(1); TTIP Proposal, Sec 3, art 6(1).

${ }^{76}$ CETA, art 8.23(2); EU-Singapore, art 9.16(1); EU-Vietnam, Ch II, Sec 3, art 7(2); TTIP Proposal, Sec 3, art 6(2).

${ }^{77}$ For a discussion on the 2006 amendments to the ICSID Arbitration Rules, see Calamita (n 48) 665. The 1976 or 2010 UNCITRAL AR do not impose any obligations of transparency, see Shirlow (n 57) 626.

${ }^{78}$ CETA, art 8.26; EU-Vietnam, Ch II, Sec 3, art 11; TTIP Proposal, Sec 3, art 8. Annex 9G of EU Singapore on public access to documents does not discuss third-party funding.
} 
and the TTIP Proposal all provide that the UNCITRAL Transparency Rules (TR) ${ }^{79}$ apply to the investment chapters, as modified by the respective FTIA provisions. ${ }^{80}$ On the other hand, EU-Singapore in Article 9.22 provides that the transparency rules in its Annex 9-G shall apply, which do not contain any references to the UNCITRAL TR.

Article 3(1) of the UNCITRAL TR provides that the following documents shall be made available to the public:

'the notice of arbitration, the response to the notice of arbitration, the statement of claim, the statement of defence and any further written statements or written submissions by any disputing party; a table listing all exhibits to the aforesaid documents and to expert reports and witness statements, if such table has been prepared for the proceedings, but not the exhibits themselves; any written submissions by the non-disputing Party (or Parties) to the treaty and by third persons, transcripts of hearings, where available; and orders, decisions and awards of the arbitral tribunal. ${ }^{, 81}$

Some of the FTIAs go further than the UNCITRAL TR. The following documents shall be added to the Article 3(1) UNCITRAL list: 'the request for consultations, the notice requesting a determination of the respondent, the notice of determination of the respondent, the agreement to mediate, the notice of intent to challenge a Member of the Tribunal, the decision on challenge to a Member of the Tribunal and the request for consolidation'. ${ }^{82}$ These documents shall also be made public by the contracting parties, prior to the constitution of the tribunal, thus expanding the list of such documents provided for in Article 2 UNCITRAL TR. ${ }^{83}$ Nevertheless, this information is subjected to the redaction of confidential or protected information. ${ }^{84}$ The FTIAs also include the exhibits among the documents (besides expert reports and witness statements) that have to be made public in accordance with Article 3(2) of the UNCITRAL TR, ${ }^{85}$ following a

\footnotetext{
${ }^{79}$ For a commentary see Dimitrij Euler, Markus Gehring and Maxi Scherer, Transparency in International Investment Arbitration - A guide to the UNCITRAL Rules on Transparency in Treaty-Based Investor-State Arbitration (CUP 2015).

${ }^{80}$ CETA, art 8.36; EU-Vietnam, Ch II, Sec 3, art 20; TTIP Proposal, Sec 3, art 18. According to art 1(7) UNCITRAL TR in case of conflict, the Rules of Transparency shall prevail over other applicable arbitration rules. However, according to art 1(8), in case of conflict with a treaty, the treaty provisions shall prevail.

${ }^{81}$ [emphasis added].

${ }^{82}$ CETA, art 8.36(2); EU-Vietnam, Ch II, Sec 3, art 20(2); TTIP Proposal, Sec 3, art 18(2)2.

${ }^{83}$ Such as the name of the disputing parties, the economic sector involved and the treaty under which the claim is brought.

${ }^{84}$ CETA, art 8.36(4); EU-Vietnam, Ch II, Sec 3, art 20(4); TTIP Proposal, Sec 3, art 18(4)2.

${ }^{85}$ CETA, art 8.36(3); EU-Vietnam, Ch II, Sec 3, art 20(3); TTIP Proposal, Sec 3, art 18(3)2.
} 
request by any person to the arbitral tribunal and provided that the Article 7 UNCITRAL TR confidentiality rules are met.

Annex 9G to EU-Singapore in Article 1(1) provides a slightly more restrictive list of documents that shall be made available to the public, but which covers most of the important ones, such as the notice of intent to arbitrate, the determination of the respondent or the awards and decisions of the tribunal. Under Article 1(2) the availability of any further documents is subject to the decision of the tribunal, proprio motu or at a request of any person, and after consulting the disputing parties. As mentioned, ISDS under EU-Singapore is in the course of being renegotiated. This means that the new version could contain references to the UNCITRAL TR and the extra documents that need to be made public provided for in the other EU FTIAs.

CETA and EU-Singapore expressly provide that hearings shall be open to the public, subject to logistical arrangements and the need to protect confidential or protected information. ${ }^{86}$ EU-Vietnam and the TTIP Proposal do not include any specific references to the public nature of the hearings. Nevertheless, they both refer to the UNCITRAL TR that in Article 6 provide for the publicness of hearings for the presentation of evidence and for oral arguments, subject to logistical possibilities and the confidentiality of certain information.

Unlike the provisions on third party funding or on the place of delivery of documents, which provide for transparency vis-a-vis a more restricted group, the provisions on the transparency of proceedings were designed for the general public, due regard having been made to confidential or protected information. Most of the FTIAs include some other provisions that are meant to provide transparency for a more restricted group. For e.g., the disputing party may disclose certain unredacted documents in the course of proceedings to persons who are connected to the proceedings, such as witnesses or experts. ${ }^{87}$ However, the protection of confidential information needs to be ensured. Article 8.37(2) CETA also does not prevent the respondent party to disclose such unredacted documents as it considers necessary in the course of proceedings, to officials from the EU, the Member States or sub-national governments, provided confidential information is protected. ${ }^{88}$

\footnotetext{
${ }^{86}$ CETA, art 8.36(5); EU-Vietnam, Ch II, Sec 3, art 20(3); TTIP Proposal, Sec 3, art 18(3); EU-Singapore, Annex 9G, art 2.

${ }^{87}$ CETA, art 8.37(1); EU-Vietnam, Ch II, Sec 3, art 20(8); TTIP Proposal, Sec 3, art 18(5).

${ }^{88}$ CETA, art 8.37(2).
} 
In this writing I shall not tackle the issue of submissions by the non-disputing treaty parties. ${ }^{89}$ The UNCITRAL TR rules in Article 5 are to be supplemented by the special rules contained in the FTIAs. ${ }^{90}$ The intervention of third parties (other than the non-disputing parties) is, however, covered in this article. The UNCITRAL TR in Article 4 allow for third party submissions other than the contracting parties; in other words, they allow for amicus curiae briefs. Such submissions, however, need to be approved by the tribunal after consultations with the disputing parties and the third party needs to prove that it has a significant interest in the proceedings. This provision is emulated in Article 3, Annex 9G to EU-Singapore. EU-Vietnam and CETA do not include any special provisions on third party interventions; thus, in their case the UNICTRAL TR will apply. The TTIP Proposal includes specific rules in Article 23 that, unlike the UNCITRAL TR, oblige the tribunal to accept the intervention of third parties if a direct and present interest of the intervener can be established.

Article 7 of the UNCITRAL TR describes in more detail the exceptions based on confidential or protected information, such as confidential business information or information of the respondent state the disclosure of which would be contrary to essential security interests. These provisions are emulated in Article 4, Annex 9G to EU-Singapore.

\subsubsection{Some Normative Suggestions}

According to Naurin and De Fine Licht, in some cases access to information regarding the reasons for taking a decision (transparency in rationale) can provide similar levels of public legitimacy as certain types of participatory mechanisms (transparency in process). Thus, even if in some instances participatory transparency cannot be achieved (for example, some hearings cannot be made public due to logistical reasons or due to the highly confidential character of the information involved), access to information, such as to the arbitral awards, the transcripts of the hearings or the submission of the parties, can still result in increased transparency and thus, increased legitimacy in the eyes of the 'public'. With this in mind, several normative suggestions are made that should be used as a template for the transparency rules of ISDS proceedings in EU FTIAs.

\footnotetext{
${ }^{89}$ See Martins Paparinskis and Jessica Howley, 'Article 5. Submission by a non-disputing Party to the Treaty' in Euler (n 75).

${ }^{90}$ CETA, art 8.38; EU-Vietnam, Ch II, Sec 3, art 25; TTIP Proposal, Sec 3, art 22; EU-Singapore, art 9.23.
} 
First, all EU FTIAs should make a (a) reference to the UNCITRAL TR since these rules address both transparency in rationale, by increasing access to information, and transparency in process, by allowing third party submissions and by making the hearings public. These rules brought two important changes to the transparency of ISDS proceedings. On the one hand, the rules managed to break the discretion the disputing parties had over the transparency of the arbitral process. Mandatory disclosure and not party autonomy is the rule. On the other hand, the discretion of the arbitral tribunals over the transparency of the proceedings has also been curtailed. $^{91}$

Second, with regard to transparency in rationale and access to information all EU FTIAs should include rules on access to/availability of the following information:

(b) The place of delivery of documents related to ISDS proceedings. This information concerns the claimants and third-party participants.

(c) The public disclosure of third-party funding and the amount of the funding. It is argued that some high-profile cases that might involve investors challenging government health or environmental regulations could involve significant third-party backing in order to push forward a specific agenda. In such a case the public is entitled to have knowledge of such funding and the amount of it. A large amount of funding could be correlated with the intention of certain groups of investors to achieve regulatory relaxation. It must also be mentioned that the disclosure of such information could negatively affect the perceived legitimacy of the ICS, if it leads to a strengthening of the public's existing convictions that strong multinationals have preferential access to such proceedings.

(d) The documents enlisted in Article 3(1) UNCITRAL TR, which relate to the arbitral proceedings, as well as the extra documents mentioned in CETA, TTIP and EU-Vietnam. ${ }^{92}$

(e) The fees of the arbitrators and the overall costs of arbitration should also be listed among the information that needs to be disclosed. As Maupin argued, some information is not readily available to the public or takes unwanted efforts to find. This data could be compiled by the European Parliamentary Research Service during the implementation phase of the FTIAs, to assess the overall financial impact of ISDS.

\footnotetext{
91 Shirlow (n 57) 642-646.

92 see $\mathrm{n} 82$.
} 
(f) Unfortunately, none of the FTIAs contain any requirements to disclose settlements in ISDS cases and in practice these are typically not publicized. A provision on the mandatory disclosure of settlements should be included in order to properly assess the overall impact of investment chapters.

Third, the highest levels of public legitimacy can be achieved if members of the 'public' can participate in a decision-making process that resembles a deliberative democratic ideal. ${ }^{93}$ Nonetheless, in case of arbitral proceedings, such participation could not include access to the deliberations of the arbitrators. Court deliberations are made behind closed doors, regardless of the national/international and standing/ad hoc nature of adjudicative bodies. The privacy of deliberations is required in order to protect the independence and impartiality of the members of the adjudicative bodies. ${ }^{94}$ Of interest to the public is the possibility to attend the hearings and submit amicus briefs. Therefore, the following suggestions are made with regard to participatory transparency:

(g) All hearings of the ICS should be open to the public, provided the logistical arrangements allow this and there is no conflict with confidential information. In the latter two scenarios access of certain MEPs (for example from the INTA Committee) should be facilitated. As previously argued, given the ever-growing distance between international decision-making and the citizen, at least elected representatives should be allowed to bridge this gap.

(h) Third party submissions should be allowed and Article 23 of Sec 3, TTIP Proposal should be used as a model. This provision ensures that the discretion of the arbitral tribunal and the disputing parties to agree to and accept third-party interventions is lowered, and it is an obligation of the tribunal to grant such interventions if a direct and present interest can be established. There is a risk of course that in high profile cases the arbitral tribunals would have to deal with a significant number of such requests for intervention, delaying thus the arbitral process.

\footnotetext{
${ }^{93}$ See $\mathrm{n} 46$.

${ }^{94}$ Aida Torres Pérez, 'Can Judicial Selection Secure Judicial Independence' in Michal Bobek (ed), Selecting Europe's Judges: A Critical review of the Appointment Procedures to the European Courts (OUP 2015) 184.
} 


\subsubsection{The EP Putting Forward Tailor-Made Solutions}

The ways in which the EP can influence the inclusion of the afore-mentioned suggestions in EU FTIAs will vary according to the four stages of 'existence' of the agreements: the agenda setting, the negotiations, the ratification, and the implementation phase. Some agreements, such as TTIP, have an uncertain future. CETA has been recently ratified by the $\mathrm{EP}^{95}$ and is awaiting Member State ratifications, as well as the request of the Belgian Government for a CJEU Opinion on the compatibility of its ISDS provisions with EU law. EU-Singapore has been concluded, but the ISDS chapter might be renegotiated and it is also awaiting the CJEU's Opinion on the question of mixity. For EU-Vietnam the negotiations have been concluded and the text was agreed, but it is not yet ratified. Furthermore, some agreements are still planned. ${ }^{96}$

(i) EU-Singapore - When looking at FTIAs for which a text is already available the obvious outlier is EU-Singapore. It does not make any reference to the UNCITRAL TR, it is lacking provisions on third party funding, and includes a more restrictive list of documents that need to be made public. If the EU manages to renegotiate the ISDS provisions in such a way as to follow the TTIP model, then some of these suggestions will be redundant. Otherwise, they should be followed.

Regardless of a specific reference to the UNCITRAL TR in the FTIAs, the rules apply if the investor-state arbitration is initiated under the UNCITRAL AR and the treaty was concluded after 1 April 2014, unless the treaty parties have agreed otherwise $\cdot{ }^{97}$ EU-Singapore would be ratified after this date and Article 9.16(1) of the agreement allows for the initiation of a case under the UNCITRAL AR. Thus, the UNCITRAL TR would apply to a future case brought under EU-Singapore, if the UNICTRAL AR are used. Nevertheless, the UNCITRAL TR would not apply to claims brought under other rules, such as those under ICSID. Furthermore, even though the Mauritius Convention does not condition the application of the UNCITRAL TR to the

\footnotetext{
95 'European Parliament Passes EU-Canada Free Trade Deal Amid Protests' (The Guardian 15 Feb 2017) <goo.gl/esp8KS> accessed 3 April 2017.

${ }^{96}$ For an updated status of ongoing negotiations see DG Trade, 'Overview of FTA and Other Trade Negotiations' <goo.gl/6gxggb> accessed 3 April 2017.

${ }^{97}$ UNCITRAL TR, art 1(1). See also Krista N Schefer, 'Article 1. Scope of Application' in Euler (n 79).
} 
usage of the UNCITRAL AR, ${ }^{98}$ it has not yet entered into force and it only applies to agreements concluded before 1 April 2014. ${ }^{99}$

Therefore, since the EP has not yet consented to EU-Singapore and negotiations might be reopened, it could make its vote conditional on a reference to the UNCITRAL TR in Article 9.22 of EU-Singapore or in Annex 9G. The EP could threaten to veto EU-Singapore if at least the UNCITRAL TR are not referred to. The optimal situation would be if all the proposed changes in Part 3.1.1 could be added. The threat of a veto can force the Commission and the Council to allow for a more informal involvement of the EP in the renegotiation process. ${ }^{100}$ The threat of a veto by the domestic legislator can also increase the bargaining power of the negotiator, because the other negotiating party will know that some issues will not be accepted by the domestic legislator of its partner. However, this can also reduce the scope of international cooperation. ${ }^{101}$ The EP does not necessarily have to veto an agreement. It can also postpone its consent until the agreement is renegotiated, such as in the case of the Passengers Name Record (PNR) agreement.

Whether the threat of a veto is politically feasible in the current climate is hard to say. The ratification of EU-Singapore is already stalled until the CJEU delivers its Opinion 2/15, requested by the Commission in order to clarify the division of competences over the agreement between the EU and its Member States. Thus, the EP might choose to avoid a further stalling of the ratification process. Furthermore, complications during the ratification process might weaken the reputation of the EU as a credible trade and investment partner and can frustrate the other contracting party. A further, more controversial argument can also be made. Some authors have argued that free trade, ${ }^{102}$ the WTO as an institution, ${ }^{103}$ and the international investment law

\footnotetext{
${ }^{98}$ Mauritius Convention, art 2(1). See Lise Johnson, 'The Mauritius Convention on Transparency: Comments on the Treaty ad its Role in Increasing Transparency of Investor-State Arbitration' (2014) CCSI Policy Paper <goo.gl/mlOjVd> accessed 3 April 2017.

${ }^{99}$ Mauritius Convention, art 1(1).

${ }^{100}$ For example, following the EP's rejection of the SWIFT Interim Agreement, the Commission and the Council were more willing to cooperate closely with the EP. During the re-negotiation the EP was consulted and MEPs would start talking directly to the American negotiators to include their proposed changes. See Katerina Meissner, 'Democratizing EU External Relations: The European Parliament's Informal Role in SWIFT, ACTA, and TTIP' (2016) 21(2) EFAR 269, 273. The EP also used the threat of a veto during the negotiations of the EU-Korea FTA in order to force the Commission to renegotiate certain clauses of the agreement, see Servent (n 34) 581.

${ }^{101}$ Putman (n 7) 448.

${ }^{102}$ Lucian Cernat, 'Trade and Global Public Goods: the unfinished agenda' (2004) The Courier ACP-EU 30. <https://goo.gl/TmREUw> accessed 3 April 2017.

${ }^{103}$ Petros C Mavroidis, 'Free Lunches? WTO as Public Good, and the WTO's View of Public Goods' (2012) 23(3) EJIL 731.
} 
system can be classified as 'global public goods'. ${ }^{104}$ If one views trade liberalisation and investment protection as global public goods, alongside for example, environmental protection, or the fight against corruption or increased transparency of international decision-making, then the chances are high that one of these public goods can interfere with the pursuit of another. Thus, blocking the ratification of an important trade deal due to transparency concerns might affect other legitimate aims, such as prosperity and economic development. The term 'global public goods', ${ }^{105}$ however, remains highly contested from the perspective of its existence and precise definition. Moreover, at least with regard to investment protection, it is hard to say whether an actual correlation exists between it and economic development.

ii. The other FTIAs - The other agreements take the UNCITRAL TR as a baseline for transparency rules and include extra provisions meant to increase transparency. Nonetheless, because none of them have yet to be fully ratified, the EP could still push for the inclusion of several minor additions or amendments, such as the public disclosure of settlements between the disputing parties or the disclosure of the amount of funding if there is third party funding. ${ }^{106}$

The EP could push for these changes via two more drastic ways; either by requesting an opinion of the CJEU under Article 218(11) TFEU or by threating to veto the agreement. The CJEU opinion is a less attractive option, because it is difficult to formulate a question on whether the FTIA's transparency provisions are compatible or not with EU law and it would stall the ratification process for several years. Furthermore, the recent EP vote against asking for such an opinion with regard to ISDS under CETA ${ }^{107}$ illustrates that this mechanism is preferably avoided even when such an important issue is at stake. If the threat of a veto or a postponed vote is chosen, the EP could push for these minor changes, especially taking into account the importance of elevating the general public's low trust in ISDS. Any further increases in transparency could result in the public accepting more the idea that an international tribunal can decide on claims brought by foreign investors against a host state. Once more, the political feasibility of such changes is questionable, given that the TTIP Proposal, CETA and EU-Vietnam already include

\footnotetext{
${ }^{104}$ Barnali Choudhury, 'International Investment Law as a Global Public Good' (2013) 17 Lewis \& Clark L Rev 481.

${ }^{105}$ Daniel Bodansky, 'What's in a Concept? Global Public Goods, International Law, and Legitimacy' (2012) 23(3) EJIL 651, 652-654; Gregory Shaffer, 'International Law and Global Public Goods in a Legal Pluralist World' (2012) 23(3) EJIL 669, 673.

${ }^{106}$ This seems unlikely for CETA, since the EP has very recently ratified it.

${ }^{107}$ EU Observer (n 36).
} 
high standards of transparency. Blocking the ratification process might also frustrate the other contracting parties.

With regard to TTIP any suggestions are subject to a very volatile political scene. Due to the recent changes in the US Executive the negotiation of TTIP is stalling. If the negotiations will continue, then a less drastic way to influence the outcome of the negotiations would be for the EP to use less formal methods, such as initiating direct talks with the other party's negotiators, increasing talks with the Commission or issuing further resolutions on transparency. For example, the EP has made use of day-to-day decision-making to informally expand its treaty powers via sending observers to on-going negotiations or even setting up direct talks with the contracting parties' negotiators. ${ }^{108}$

Thus far the negotiations of TTIP ushered in the even greater involvement of the EP during the negotiations. The EP, MEPs and EP Committees demanded access to all the negotiating documents. ${ }^{109}$ Furthermore, the EP demanded to increase the frequency of oral debriefings by the Commission, it set up working and monitoring groups, the EP's President created a coordination group to debate different issues surrounding TTIP, and the EP issued resolutions and even communicated a comprehensive list of concrete substantial changes. ${ }^{110}$ The EP's 8 July 2015 Resolution on TTIP includes several points on the need to increase transparency, civil society involvement and public and political outreach. Among others, the EP urged the Commission to make more negotiation proposals available to the general public, to provide access to all negotiating document for MEPs, to promote close engagement with the Member States and their parliaments and to promote continuous and transparent engagement with a wide range of stakeholders. ${ }^{111}$ Furthermore, the MEPs and members of the US Congress regularly meet and discuss pertinent issues on EU-US relations in the Transatlantic Legislator's Dialogue (TLD) and participate in informal diplomatic visits. ${ }^{112}$

\footnotetext{
${ }^{108}$ Servent (n 34) 578-580.

${ }^{109}$ Meissner (n 100) 282.

110 ibid 282-284. See Balázs Horváthy and Viktor Szép, 'International Trade Agreements Captured by Domestic Politics? Lessons Learnt from the CETA Case' (2016) HAS Centre for Social Sciences <goo.gl/vwALPa> accessed 3 April 2017.

${ }^{111}$ EP Resolution (n 11) point 2(e).

112 Jančić 2016 (n 15) 898-902.
} 
iii. Future Agreements - In the case of agreements that have yet to be negotiated, the EP should push for all the normative suggestions mentioned in Part 3.1.2 in the various stages of the agreements' existence.

One could assume that the role of the EP in the agenda setting phase is minimal, since under Article 207(3) TFEU ${ }^{113}$ it is the Council that shall authorize the opening of negotiations via the adoption of negotiating directives. ${ }^{114}$ However, as mentioned, the EP under Article 218(10) TFEU possesses a formal right to be 'informed' 'immediately and fully' at all stages of the conclusion of an international agreement. The 2010 Interinstitutional Agreement between the EP and the Commission (2010 IA) elaborates the EP's right to be informed further ${ }^{115}$ by including the negotiating directives, ${ }^{116}$ the Commission's intention to initiate negotiations, and the draft negotiating directives ${ }^{117}$ among the information the Commission needs to provide the EP.

The agenda setting stage is of great importance, because the negotiating directives set out the guidelines according to which the Commission shall conduct the negotiations, including the issues which can be negotiated. ${ }^{118}$ Therefore, already in this phase the EP should request informal consultations with the Commission and issue resolutions ${ }^{119}$ in which it calls for increased transparency, by including the UNCITRAL TR and the afore-mentioned extra normative suggestions. Some MEPs could even participate in the agenda setting phase, such as in the case of the re-negotiation of the SWIFT Agreement. ${ }^{120}$

Resolutions should be issued prior to the beginning of negotiations, as future guidelines for the Commission. For example, in the case of TTIP the EP issued its 2013 Resolution prior to the Council authorizing the negotiating mandate. The Commission could thus take into account the

113 art 218 TFEU prescribes in a general manner the role of the EU institutions during the negotiation and conclusion of international agreements. These provisions are subject to the special provisions of art 207 TFEU that concern the common commercial policy (CCP) and the conclusion of international trade and investment agreements.

${ }^{114}$ Council of the EU, 'Negotiating Directives CETA 2009' (partially declassified on 15 Dec 2015) <https://goo.gl/mFFXQ4> accessed 3 April 2017 and Council of the EU 'Amendment to CETA Negotiating Directives 2011' (partially declassified on 15 Dec 2015) <https://goo.gl/slcHu7> accessed 3 April 2017.

${ }^{115}$ See also art 295 TFEU on interinstitutional agreements.

1162010 IA point 23.

${ }^{117}$ Annex III to the 2010 IA, points 1 and 2.

${ }^{118}$ The negotiating directives can be later amended.

${ }^{119}$ The EP can issue resolutions to set broad agendas in a specific policy field in which international agreements will be concluded, such as the 2011 EP Resolution on the future of EU investment policy (P7-TA(2011) 0141) or narrower resolutions targeting a specific agreement, such as the 2013 Resolution on trade and investment negotiations with the US (B7-0187/2013).

${ }^{120}$ Servent (n 34) 578-579. 
position of the EP before launching the negotiations, which also included making the results of the TTIP negotiating rounds public. ${ }^{121}$

The 2016 Interinstitutional Agreement (2016 IA) between the EP, the Council and the Commission on Better Law-Making further strengthens the position of the EP, providing that it exercises its powers on an equal footing with the Council. ${ }^{122}$ The 2016 IA also provides that the Commission will carry out impact assessments ${ }^{123}$ that shall be presented to the EP and the Council. ${ }^{124}$ The EP can then invite the Commission to complement the impact assessments. ${ }^{125}$ The Commission will also hold public consultations in an 'open and transparent' manner before adopting a proposal, the results of which shall be communicated to both co-legislators. ${ }^{126}$

Influencing the negotiation phase is also crucial, ${ }^{127}$ given the specialized and technocratic character of modern negotiations. ${ }^{128}$ Similarly to the agenda-setting phase, the EP possesses less formal powers than the Commission or the Council. Unlike the Council, the EP is not given direct oversight over the negotiation process. Nevertheless, Article 207(3) TFEU also provides that the Commission shall report regularly to the EP during the negotiations. Furthermore, the EP's general right to be informed applies to all stages of an international agreement's existence, including the negotiations. ${ }^{129}$ Moreover, under the 2010 IA the Commission has an obligation to 'take due account of Parliament's comments throughout the negotiations, ${ }^{130}$ and at the EP's

${ }^{121}$ Meissner (100) 280. The results of the negotiating rounds are available here: <https://goo.gl/mF6N0w> 3 April 2017.

1222016 IA, points 32 and 33.

${ }^{123}$ Impact assessments can function as 'instruments to exercise political control over bureaucracies or to offer regulatory legitimacy'. Cornelia Klugman, 'Oversight of the US Executive - The Congressional Experience and its Lessons for the EU' (2016) European Parliamentary Research Service PE 593.501, 26.

${ }^{124}$ IA 2016, point 13. For a list of impact assessments see DG Trade, 'Assessments' <https://goo.gl/WY0BsM> 3 April 2017. DG Trade, 'EU-Canada SIA Final Report' (2011) Trade 10/B3/B06 <https://goo.gl/er8QpA > 3 April 2017.

125 ibid point 15 .

126 ibid point 19.

127 Joost Pauwelyn argues that ISDS should not be included in EU FTIAs because they might block the negotiation or conclusion of the agreements. See 'If Wallonia Blocks CETA because of Investor-State Dispute Settlement (ISDS) Why not Take ISDS out of CETA?' (2016) International Economic Law and Policy Blog <https://goo.gl/bsf3tt> 3 April 2017.

${ }^{128}$ Andrés Rozental and Alicia Buenrostro, 'Bilateral Diplomacy' in Andrew F Cooper et al (eds), The Oxford Handbook of Modern Diplomacy (OUP 2013) 233.

${ }^{129}$ Mauritius Transfer (n 35) para 85; Tanzania Transfer (n 24) para 68. The EP has to be immediately and fully informed at all stages of the conclusion of an international agreement, even if the agreement refers exclusively to the CFSP, a policy area in which the EP's consent is not required.

1302010 IA, Annex III, points 3 and 4. 
request the Commission shall facilitate the inclusion of a delegation of MEPs as observers in EU delegations. ${ }^{131}$

As mentioned in the previous sub-Section, the EP should send observers to on-going negotiations, set up direct talks with the contracting parties, have regular briefings by the Commission, consult with stakeholders and have access to any interim texts. This way the EP can check whether its suggestions in the agenda setting phase have been followed by the Commission. Furthermore, if an issue becomes contentious among the EU electorate during the negotiations, threatening to affect the legitimacy of a mechanism involving investment protection, the EP could react to the concerns of the EU electorate in a timely fashion.

During the ratification phase the EP can also threaten with a veto if the normative suggestions have not been taken into consideration or it can postpone its vote. The Commission also has an obligation to inform the EP of the initialling of an agreement and its provisional application. ${ }^{132}$

The implementation phase is also very important. The EP should avail itself of the right to intervene as a third party in potential investor-state arbitral proceedings in cases involving sensitive public policy issues that might disgruntle the EU electorate. Furthermore, certain MEPs from the INTA Committee or other interested committees should attend the public hearings as observes. The EP could also ask its Research Services to conduct post-ratification evaluations ${ }^{133}$ to check whether the list of documents that need to be made publicly available during the ISDS proceedings, are actually made available; to evaluate how the transparency requirements are complied with; and to compile various sets of data on the costs of ICS proceedings, the remuneration of arbitrators, third party funding, etc. In case of future treaty modifications ${ }^{134}$ that involve transparency measures, the EP should issue resolutions and set up consultations with the Commission and the Council.

The likelihood is quite high that the EU will be a respondent in future ICS cases brought under the FTIAs. Whilst Article 218(9) TFEU requires Council approval in order for the Commission to defend the EU's position in a body set up under an international agreement, the

\footnotetext{
131 The MEPs shall not participate in the negotiations but can be granted observer status, subject to the 'legal, technical and diplomatic possibilities'. 2010 IA, Annex III, point 25.

1322010 IA, point 24.

133 Klugman (n 123) 27.

1342010 IA, Annex 3, point 9 provides that for international agreements that fall under the consent procedure 'the Commission shall also keep Parliament fully informed before approving modifications to an agreement which are authorised by the Council'.
} 
CJEU has clarified that Council approval is not needed if the Commission is defending the EU before an international adjudicative body. ${ }^{135}$ Thus, the Commission would not need the approval of the Council to defend the EU in an investor-state case. But, where does the EP fit into all of this? One could argue that the duty of sincere cooperation read together with the general right of the EP to be informed in all stages of the conclusion of an international agreement ${ }^{136}$ would require the Commission to inform the EP of any cases in which the EU is respondent and supply the EP or certain MEPs with the position the EU will take before the arbitral tribunals.

\begin{tabular}{|c|c|c|c|c|}
\hline \multirow[t]{3}{*}{ PHASE } & \multirow{3}{*}{$\begin{array}{c}\text { EP } \\
\text { OVERSIGHT }\end{array}$} & \multicolumn{3}{|c|}{ INVESTOR-STATE PROCEEDINGS } \\
\hline & & \multicolumn{2}{|c|}{ Existing EU FTIAs } & \multirow[t]{2}{*}{ Future EU FTIAs } \\
\hline & & EU-Singapore & Other FTIAs & \\
\hline \multirow{2}{*}{\multicolumn{2}{|c|}{ Proposed Changes }} & \multicolumn{3}{|c|}{$\begin{array}{l}\text { (a) reference to UNCITRAL TR (b) place of delivery of documents } \\
\text { (c) } 3^{\text {rd }} \text { party funding and amount (d) UNCITRAL TR-extra documents } \\
\text { (e) costs/fees made public (f) disclosure of settlements (g) publicity of } \\
\text { hearings expressly stated (h) } 3^{\text {rd }} \text { party submissions follow TTIP model }\end{array}$} \\
\hline & & $\begin{array}{l}\text { All (a-h) but (a) } \\
\text { feasible }\end{array}$ & $\begin{array}{l}\text { (a) already included } \\
\text { (c) }+(\mathrm{e})+(\mathrm{f}) \text { for all } \\
\text { (b) }+(\mathrm{g})+(\mathrm{h}) \text { for some } \\
\end{array}$ & All (a-h) \\
\hline \multirow[t]{2}{*}{ Agenda setting } & Formal tools & $\mathrm{X}$ & $\mathrm{X}$ & $\begin{array}{l}\text { right to be informed; } \\
\text { invite COM to } \\
\text { complement ImpA }\end{array}$ \\
\hline & Informal tools & $\mathrm{X}$ & $\mathrm{X}$ & $\begin{array}{l}\text { resolutions; consultations } \\
\text { MEP participation; }\end{array}$ \\
\hline \multirow[t]{2}{*}{ Negotiations } & Formal tools & $\mathrm{X}$ & $\mathrm{X}$ & $\begin{array}{l}\text { right to be informed; } \\
\text { COM reports regularly }\end{array}$ \\
\hline & Informal tools & $\begin{array}{l}\text { direct talks with other } \\
\text { negotiators; } \\
\text { consultations with } \\
\text { COM }\end{array}$ & $\begin{array}{l}\text { threat of veto?; direct } \\
\text { talks with other } \\
\text { negotiators; COM oral } \\
\text { debriefings }\end{array}$ & $\begin{array}{l}\text { threat of veto; direct } \\
\text { talks with foreign } \\
\text { negotiators; resolutions; } \\
\text { working groups; }\end{array}$ \\
\hline \multirow[t]{2}{*}{ Ratification } & Formal tools & $\begin{array}{l}\text { veto unlikely for EUSG } \\
\text { postponed consent? }\end{array}$ & $\begin{array}{l}\text { veto unlikely for CETA } \\
\text { postponed consent? }\end{array}$ & $\begin{array}{l}\text { right to be informed; } \\
\text { veto; postponed consent }\end{array}$ \\
\hline & Informal tools & \multicolumn{3}{|c|}{ consultations with COM and Council } \\
\hline \multirow[t]{2}{*}{ Implementation } & Formal tools & \multicolumn{3}{|c|}{$\begin{array}{l}\text { obligation of COM to inform EP about ISDS cases, modification of FTIAs; } \\
\text { EP intervenes in ISDS as } 3^{\text {rd }} \text { party; }\end{array}$} \\
\hline & Informal tools & \multicolumn{3}{|c|}{$\begin{array}{l}\text { consultations with COM; MEP observers in treaty bodies; } \\
\text { EPRS ex post evaluations; resolutions to modify FTIAs }\end{array}$} \\
\hline
\end{tabular}

Fig 2 - Proposed changes for the transparency of investor-state arbitral proceedings

COM - Commission; ImpA - Impact Assessment; EPRS - EP Research Service

${ }^{135}$ Case C-73/14 Council v Commission (ITLOS) EU:C:2015:663, para 63. Under art 335 TFEU the Commission is to represent the EU in legal proceedings.

136 art 218(10) TFEU. 


\subsection{Transparency in Treaty Committees}

\subsubsection{Extensive Powers of Interpretation, but No Transparency?}

When discussing issues of transparency that concern international investment law, the proceedings of investor-state tribunals gain most of the attention. Besides international adjudicative bodies, however, contracting parties also set up other international bodies. Contracting parties can have multiple reasons for establishing treaty bodies, such as providing these bodies with the power to interpret ${ }^{137}$ or supervise the implementation of the international agreement. ${ }^{138}$ Nonetheless, the transparency of the decision-making of such bodies is often overlooked in academia.

With regard to their structure, most treaty bodies will include a central organ, 'but depending on their functions and relationship to other treaties, subsidiary bodies and a secretariat may also be established'. ${ }^{139}$ CETA provides for a Joint Committee ${ }^{140}$ while the TTIP Proposal, ${ }^{141}$ EU-Singapore ${ }^{142}$ and EU-Vietnam ${ }^{143}$ provide for a Trade Committee. The Joint/Trade Committees ('central committees') are co-chaired by the Minister responsible for Trade of the non-EU contracting party and the Member of the EU Commission responsible for Trade. They meet regularly once every year or every two years in the case of EU-Singapore. ${ }^{144}$ All the EU FTIAs under discussion also provide for specialized sub-committees that are established under the auspices of the central committees, such as committees on trade in goods, customs ${ }^{145}$ or, for the purposes of this article, committees on services and investment. ${ }^{146}$

\footnotetext{
${ }^{137}$ See Birgit Schlütter, 'Aspects of Human Rights Interpretation by the UN Treaty Bodies' in Helen Keller and Geir Ulfstein (eds) UN Human Rights Treaty Bodies. Law and Legitimacy (CUP 2012) 261.

${ }^{138}$ Geir Ulfstein, 'Treaty Bodies and Regime' in Duncan B Hollis (ed), The Oxford Guide to Treaties (OUP 2012) 428, 429-430. For a classification of treaty bodies (commissions or committees) see Henry G Schermers and Niels M Blokker, International Institutional Law (Martinus Nijhoff, $5^{\text {th }}$ Revised ed 2011) $§ 421-431$, who classify them into functional, consultative, ad hoc advisory, procedural and regional commissions.

${ }^{139}$ Ulfstein (n 138) 430.

${ }^{140}$ CETA, art 26.1. For a further discussion see Gáspár-Szilágyi (n 51).

${ }^{141}$ The TTIP text is not yet finalized. From the Commission's November 2015 Proposal on TTIP's Investment Chapter one can assume that the central body would be the Trade Committee. See TTIP Proposal, Sec 2, art 3(3).

142 EU-Singapore, art 17.1.

${ }^{143}$ EU-Vietnam, Ch XX, art X.1.

${ }^{144}$ EU-Singapore, art 17.12.

${ }^{145}$ CETA, art 26.2; EU-Singapore, art 17.2.1; EU-Vietnam, Ch XX, art X.2.1.

${ }^{146}$ CETA, art 26.2(b) 'Committee on Services and Investment'; EU-Singapore, art 17.2.1(d) 'Committee on Trade in Services, Investment and Government Procurement'; EU-Vietnam, Ch XX, art X.2.1(b) 'Committee on Services, Investment and Government Procurement'.
} 
The types of functions and powers treaty bodies enjoy vary according to the provisions of their constitutive treaties. The central committees in the EU FTIAs have a set of mandatory and optional functions enumerated in the agreements' final and institutional provisions. Thus, they 'shall' supervise and facilitate the implementation of the FTIAs, supervise the work of the specialized committees, adopt decisions, etc. ${ }^{147}$ The central committees 'may' also delegate responsibilities to specialized committees, consider or agree on amendments to the agreements, communicate with all interested parties including private sector and civil society organizations, etc. ${ }^{148}$ Furthermore, these committees have the power to provide interpretations of the FTIAs that shall be binding on investor-state or state-to-state tribunals established under the agreements. ${ }^{149}$ In other words, under the EU FTIAs the arbitral tribunals do not possess exclusive interpretive powers over the agreements, but must share them with the central committees. ${ }^{150}$

In light of the far-reaching powers of these committees, it is baffling that none of the EU FTIAs provide for rules on the transparency of their decision-making process. Of the EU FTIAs analysed, only CETA provides for the prompt set-up of contact points that shall monitor the works of all institutional bodies and respond to any information requests by interested persons and the other contracting party. ${ }^{151}$ As mentioned, the central committees may also communicate with members of the private sector and civil society organizations. However, no provisions are included on the mandatory disclosure of information or the possibility of the 'public' to participate in committee meetings.

\subsubsection{Five Main Suggestions}

Whilst the legitimacy of ISDS proceedings has received ample academic discussion, the workings of treaty committees seem not to have generated any significant public legitimacy concerns. One possible explanation might be that in treaty committees the contracting parties retain control over the outcome of the decisions, as opposed to ISDS proceedings in which a contracting party can only act as a respondent that is bound by the decisions of an arbitral

\footnotetext{
${ }^{147}$ CETA, art 26.1.4; EU-Singapore, art 17.1.3; EU-Vietnam, Ch XX, art X.1.3.

${ }^{148}$ CETA, art 26.1.5; EU-Singapore, art 17.1.4; EU-Vietnam, Ch XX, art X.1.4.

${ }^{149}$ CETA, art 26.1.5 and art 8.31.1; EU-Singapore, art 9.19.3 and art 17.1.4(4); EU-Vietnam, CH II, Sec 3, art 16.2.4 and EU-Vietnam, Ch XX, art X.1.4(d); TTIP Proposal, Sec 3, art 13.2.5 .

${ }^{150}$ See Anthea Roberts, 'Clash of Paradigms: Actors and Analogies Shaping the Investment Treaty System' (2013) 107 AJIL 45, 78-79.

${ }^{151}$ CETA, art 26.6.
} 
tribunal. The only normative concerns that led to ample academic discussions relate to the power of such committees to interpret the agreements in a binding fashion and the ways in which this might affect the arbitral process. ${ }^{152}$

The above notwithstanding, the lack of any transparency provisions concerning the decision-making process of treaty committees should raise concerns as to their public legitimacy. Such decisions are taken beyond the Member State or EU decision-making processes, often without the public being aware of them and without proper parliamentary oversight. As discussed, even modest transparency in rationale reforms can lead to increases in legitimacy similar to certain mechanisms of transparency in process. In the following paragraphs normative suggestions are made, taking into account the subject matter and the addressees of transparency provisions concerning treaty committees dealing with investment issues.

First, with regard to transparency in rationale and access to information, as a minimum (a) access to the following information should be provided to the general public: the dates of the various committee meetings, the list of participants, the agenda of the meetings, a transcript of deliberations, the positions taken by the treaty parties, and the final committee decisions. The regular disclaimer in the case of highly sensitive information should apply to the general public. Nevertheless, certain MEPs (e.g. INTA Committee members) should be granted access to more sensitive information. It is paramount that at least the decisions of the treaty committees are made public, since these bodies have a high level of influence over the interpretation, supervision and implementation of these agreements.

Second, what about transparency in process and participation? As discussed, not all forms of participatory transparency will lead to increased legitimacy compared to methods of transparency in rationale. One could thus conclude that making the afore-mentioned information available to the public would suffice. Nevertheless, as Naurin's and De Fine Licht's research shows, when the decision-making process emulates some form of 'deliberative democratic ideal', legitimacy is further increased. This could be achieved by:

(b) Allowing third party submissions during or before the meetings of these committees. Similarly to the third-party submission rules for the ICS proceedings, a direct interest would need to be shown and the discretion of the committees to reject a submission should be lowered.

\footnotetext{
${ }^{152}$ See Charles H Brower, II, 'Why the FTC Notes of Interpretation Constitute a Partial Amendment of NAFTA Article 1105’ (2005-2006) 46 Virginia JIL 347; Kaufmann-Kohler (n 14).
} 
(c) Prior to the committee meetings public consultations could be organized if the issue is highly contentious and would touch upon public policy concerns. This would be required due to the ever-increasing decisions that are made on the international level, far away from the citizen.

(d) As a bare minimum (d1) MEPs, as representatives of the EU electorate, should be allowed by default to act as observers during these committee meetings. It would be optimal if (d2) certain representatives of civil society were also given the opportunity to observe these committee meetings.

\subsubsection{How to Do It?}

The formal powers of the EP concerning the workings of treaty bodies are few and far between. EU primary law in Article 218(9) TFEU only provides that the Council shall adopt a decision, on a proposal by the Commission, establishing 'the position to be adopted on the Union's behalf in a body set up by an agreement'. As the CJEU has clarified, the Council decision is needed when the EU has to express its position 'in' an international body, not 'before' it. ${ }^{153}$

In case of the EP, the TFEU only provides for its right to be 'immediately and fully' informed under Article 218(10) TFEU. The 2010 IA in point 26 further elaborates the EP's right to be informed. It provides that the 'the Commission shall keep Parliament systematically informed about, and facilitate access' of MEPs as observers in EU delegations to the meetings of multilateral treaty bodies, when the decisions taken by such bodies need the EP's consent to implement them or require 'the adoption of legal acts in accordance with the ordinary legislative procedure.' Whilst this provision clearly covers trade and investment related issues, a broader interpretation should also cover not just multilateral treaty bodies, but also bilateral ones.

The lack of substantial formal powers regarding the workings of treaty committees, does not mean that the EP cannot prevail itself of the various formal and informal powers it possesses in the pre- and post-ratification phases of international agreements. Similarly to the discussion in Part 3.1.3, a difference has to be made between agreements for which a text is already available and future agreements.

${ }^{153}$ ITLOS (n 37) para 63. In Case C-399/12 Germany v Council (OVI) EU:C:2014:2258 the CJEU held that the EU can take a position in an international body, even if it is not a signatory to the agreement. 
i. Existing FTIAs - In case of CETA and EU-Vietnam the texts are already finalized, while TTIP's future is uncertain and the Investment Chapter of EU-Singapore might be renegotiated. With regard to CETA and EU-Vietnam, the EP could only exert its influence during the ratification or in the post-ratification phase. In the case of CETA the threat of a veto or of a postponed consent is not a possibility anymore, because the EP has recently ratified it. Such a threat might work during the ratification of EU-Vietnam; as a bare minimum the EP should push for public access to the decisions and other documents relating to the decision-making process of treaty committees. These changes would mostly be added in the final, institutional provisions of the agreement. Nevertheless, even if the ratifications go through without modifications, in the implementation phase the EP could pressure the Commission to allow for MEP observers to attend such committee meetings. Furthermore, the EP can avail itself of its right to be informed of the position the Commission intends to take in such committees.

In the case of TTIP, if the negotiations will be continued, the EP should voice its concerns to the Commission regarding the transparency of the workings of treaty committees, before the next negotiating rounds. The EP should also set up direct talks with the US negotiators. It would be optimal if the EP could push through all the suggestions mentioned in the previous sub-section: the public access to the committee decisions and other documents, third-party submissions, public consultations in case of serious concerns, and the observer status for MEPs and/or for representatives of civil society. If EU-Singapore's renegotiation is a possibility, then the EP should have a similar strategy as the one for TTIP.

ii. Future agreements - In the case of future agreements the EP can avail itself of all its formal and informal powers, already in the agenda setting phase. The EP should make it clear to the Commission in the agenda setting phase via a resolution and subsequent consultations that it wishes to increase the transparency of the workings of treaty committees. Preferably, the EP should push for all the afore-mentioned suggestions. The following table also exemplifies some of the other measures the EP can take in the post-agenda setting phases. 


\begin{tabular}{|c|c|c|c|}
\hline \multirow[t]{2}{*}{ PHASE } & \multirow[t]{2}{*}{ EP OVERSIGHT } & \multicolumn{2}{|c|}{ WORKINGS OF TREATY COMMITTEES } \\
\hline & & Existing EU FTIAs & Future EU FTIAs \\
\hline \multirow{2}{*}{\multicolumn{2}{|c|}{ Proposed Changes }} & \multicolumn{2}{|c|}{$\begin{array}{l}\text { (a) committee decisions and other docs made public } \\
\text { (b) third party submissions (c) public consultations } \\
\text { (d1) MEPs observers (d2) Civil society reps. observers }\end{array}$} \\
\hline & & Minimum: (a) & Optimal (a)+(b)+(c)+(d1)+(d2) \\
\hline \multirow[t]{2}{*}{ Agenda setting } & Formal tools & $\mathrm{X}$ & invite COM to complement ImpA \\
\hline & Informal tools & $\mathrm{X}$ & resolutions, consultations \\
\hline \multirow[t]{2}{*}{ Negotiations } & Formal tools & $\mathrm{X}$ & $\begin{array}{l}\text { right to be informed; } \\
\text { COM reports regularly }\end{array}$ \\
\hline & Informal tools & $\begin{array}{l}\text { threat of veto for EU-Vietnam; } \\
\text { direct talks with foreign } \\
\text { negotiators for TTIP \& EUSG* }\end{array}$ & $\begin{array}{l}\text { threat of veto; direct talks with } \\
\text { foreign negotiators; resolutions; } \\
\text { working groups; }\end{array}$ \\
\hline \multirow[t]{2}{*}{ Ratification } & Formal tools & $\begin{array}{l}\text { veto unlikely for CETA; postpone } \\
\text { consent? }\end{array}$ & $\begin{array}{l}\text { veto; postponed consent; } \\
\text { right to be informed }\end{array}$ \\
\hline & Informal tools & \multicolumn{2}{|c|}{ consultations with COM on possible modifications? } \\
\hline \multirow[t]{2}{*}{ Implementation } & Formal tools & \multicolumn{2}{|c|}{$\begin{array}{l}\text { MEP observers under IA } 2010 \text { p 26; Obligation of COM to inform of } \\
\text { treaty body meetings }\end{array}$} \\
\hline & Informal tools & \multicolumn{2}{|c|}{ consultations with COM; resolutions; EPRS evaluations } \\
\hline
\end{tabular}

Fig 3 - Proposed changes for the transparency of investor-state arbitral proceedings

$*$ provided the TTIP negotiations will continue

\subsection{Transparency When Selecting the Arbitrators}

Another thorny issue that has received significant academic attention concerns the decision-makers of investor-state disputes, the arbitrator-judges. Criticisms range from the alleged lack of sufficient independence and impartiality of the arbitrators, to the vested interest of the arbitrators to perpetuate the regime. ${ }^{154}$ The upcoming sections do not have as their main focus the independence and impartiality of the arbitrator-judges. Instead they focus on the levels of transparency during the process through which the arbitrators get nominated and appointed ('the selection process'). Nevertheless, it is acknowledged that transparency of the selection process might bolster the independence of the adjudicators, which ultimately affects the perceived legitimacy of the adjudicative body. ${ }^{155}$ According to the traditional perception, the legitimacy of $a d$ hoc arbitration bodies stems directly from the disputing parties' consent. ${ }^{156}$ The

\footnotetext{
${ }^{154}$ Gabrielle Kaufmann-Kohler and Michele Potestà, 'Can the Mauritius Convention Serves as a Model for the reform of investor-State arbitration in connection with the introduction of a permanent investment tribunal or an appeal mechanism?' (2016) CIDS Working Paper, 11-12; See also Stavros Brekoulakis, 'Systemic Bias and the Institution of International Arbitration: A New Approach to Arbitral Decision-Making' (2013) 4(3) JIDS 553; Joost Pauwelyn, 'The Rule of Law Without the Rule of Lawyers? Why Investment Arbitrator are from Mars, Trade Adjudicators are from Venus' (2015) 109(4) AJIL 761; Susan Frank, 'The Diversity Challenge: Exploring the "Invisible College" of International Arbitration (2015) 53 Columbia J Trans'l Law 429.

${ }_{155}$ Pérez (n 94) 195-196.

$156 \mathrm{ibid}$ 185. In the case of ISDS the host state will give its consent first in the treaty. It functions as a standing offer which the investor accepts via its own consent materialized through the decision to bring a claim against the host
} 
EU FTIAs move away from the traditional ad hoc arbitral model and create a standing ICS. This means that its legitimacy should be grounded in factors other than the consent of the disputing parties, ${ }^{157}$ such as the transparency of the selection process.

\subsubsection{A More Robust System, but What about Transparency?}

The default rule in the overwhelming number of existing IIAs is the discretion of the disputing parties to choose ad hoc arbitrators. Thus, the investor and the host state regularly choose one arbitrator each and by common decision appoint the third arbitrator. ${ }^{158}$ There is a risk, however, that party-appointed arbitrators might favour the party that appointed them and that arbitrators might favour investors in order to ensure future opportunities for work. ${ }^{159}$

The recent EU FTIAs part from the existing practice and contemplate two-tier standing Investment Courts, ${ }^{160}$ with the exception of the current version of EU-Singapore, which only provides for the possibility of setting up an appellate body. The discretion of the disputing parties to choose the arbitrators is replaced with the power of the central treaty committees to appoint a list of arbitrators to act on the first instance tribunals and the appellate bodies, equally split between nationals of the EU, the other contracting party and third countries. The tribunals shall hear cases in divisions of three members, each member belonging to one of the three national groups. ${ }^{161}$ CETA also provides that the sub-committee on Services and Investment shall periodically review the functioning of the Appellate Tribunal and may make recommendations to the CETA Joint Committee. ${ }^{162}$

Once again, EU-Singapore is the outlier since it preserves to some extent the disputing party appointment rule. In this case the Trade Committee establishes a list of individuals to act as

state, see Guiguo Wang, 'Consent in Investor-State Arbitration: A Critical Analysis' (2014) 13 Chinese Journal of International Law 335.

157 ibid 185.

${ }^{158}$ For a comparison between the appointment of ICSID arbitrators and WTO panellists, see Pauwelyn 2015 (n 154) 784-786.

159 J Anthony van Duzer, 'Investor-State Dispute Settlement in CETA: Is it the Gold Standard' (2016) Commentary No. 459, C.D. Howe Institute, 4.

${ }^{160}$ On TTIP see Kyle D Dickson-Smith, 'Does the European Union Have New Clothes?: Understanding the EU's New Investment Treaty Model' (2016) 17 JWIT 773, 794-796. Szilárd Gáspár-Szilágyi, 'A Standing Investment Court under TTIP from the Perspective of the CJEU' (2016) 17(5) JWIT 701.

161; EU-Vietnam, Ch II, Sec 3, arts 12 and 13; TTIP Proposal, Sec 3, arts 9 and 10.

${ }^{162}$ CETA, art 8.28(8). 
arbitrators, but the disputing parties each choose their own arbitrators, and by agreement they shall choose a third arbitrator to preside over the proceedings. ${ }^{163}$

In an effort to further increase the public legitimacy of ISDS, the EU FTIAs also try to tackle some of the criticisms regarding the independence and impartiality of the arbitrators. The agreements include provisions on the qualifications of the arbitrator-judges, ${ }^{164}$ as well as rules of ethics and conduct. The arbitrator-judges shall possess the necessary qualifications in their respective countries for appointment to judicial office, or be jurists of recognised competence. They shall have demonstrated expertise in public international law and ought to have knowledge of international investment law and trade law. ${ }^{165}$ Furthermore, the arbitrator-judges shall be independent, ${ }^{166}$ without any affiliation to any government and shall not participate in the consideration of disputes that could create a direct or indirect conflict of interest. They shall also refrain from acting as council or party-appointed expert or witness in any pending or new investment protection disputes under any other agreement or domestic law. ${ }^{167}$

From the above it is fairly evident that the appointment of the arbitrators and any oversight of the workings of the tribunals is done by the treaty committees, which in turn are made-up of representatives of the EU 'executive' and the other contracting party's government. Nonetheless, no provisions exist on the transparency of the selection process.

\subsubsection{Differentiated Normative Suggestions. Who Are the Addressees?}

One has to first acknowledge the improvements the proposed investment courts would bring. The influence of the investors over the appointment of arbitrator-judges is taken away completely or partially in case of EU-Singapore, making the appointment process a lot more court like than

\footnotetext{
${ }^{163}$ EU-Singapore, arts 9.18.

164 Whilst EU-Singapore refers to arbitrators, the TTIP Proposal refers to judges.

${ }^{165}$ CETA, arts 8.27(4) and 8.28(4); EU-Singapore, art 9.28(6); EU-Vietnam, Ch II, Sec 3, arts 12(4) and 13(7); TTIP Proposal, Sec 3, arts 9(4) and 10(7).

166 Even so, some argue that CETA's arrangements concerning the independence of decision-makers could be improved, because they do not provide a fixed compensation to decision-makers, security of tenure and they are not completely prohibited from all outside activities that could compromise their independence. See Van Duzer (n 159) 16; Gus van Harten, 'ISDS in the Revised CETA: Positive Steps, But is it a "Gold Standard"?' <https://goo.gl/yFreJL> accessed 3 April 2017.

${ }^{167}$ CETA, art 8.30; EU-Vietnam, Ch II, Sec 3, art 14; TTIP Proposal, Sec 3, art 11. EU-Singapore, art 9.28(7) does not provide such stringent conditions. See also Van Duzer (n 159) 4.
} 
traditional arbitral appointments. ${ }^{168}$ One cannot thus argue that the EU, via DG Trade, will not have sufficient influence over who becomes an arbitrator-judge. Nevertheless, in the present case a peculiar situation arises. An international decision-making body (a treaty committee) decides on the make-up of an international adjudicative body (the ICS). The latter in turn, will deliver decisions in cases that involve the same contracting parties that make up the appointing treaty committee. From the perspective of investor-claimants, such a system raises concerns of impartiality that might affect how they perceive the legitimacy of the ICS. However, part of the general public that opposes traditional ISDS due to the strong influence of investors in the appointment process, might find the appointment of ICS members more legitimate.

The above notwithstanding, is there a normative argument to be made that at least some form of transparency of the selection process should be provided? As discussed, providing even modest levels of transparency in rationale can contribute to the perceived legitimacy of a decision-making process in a fashion similar to certain forms of transparency in process. One also needs to acknowledge that in the present case not all forms of transparency might be advisable and a difference has to be made between transparency vis-à-vis the EP and the general public. In this case the EP is also an addressee of transparency.

With regard to the general public, the type of participatory transparency that implies the submission of ideas/documents by the 'general public' or the public character of the hearings in which the candidates are assessed, is not particularly feasible. ${ }^{169}$ Such suggestions would most probably over-politicize ${ }^{170}$ the matter, create lengthy appointments, and raise concerns of arbitrator independence and impartiality. ${ }^{171}$ There is, however, a more feasible solution. Increased legitimacy could still be obtained by using transparency in rationale methods, such as (a) making information public on: the call for candidates, the conditions candidates need to fulfil,

168 Sergio Puig, 'Blind Appointments and International Arbitrators' (2016) Kluwer Arbitration Blog <https://goo.gl/HaHldL> accessed 3 April 2017. One could argue though that this way the appointed arbitrator judges might be biased towards the appointing entity.

${ }^{169}$ Nonetheless, some jurisdictions organize public consultations for the selection of domestic judges with the participation of civil society organizations or academia. See Pérez (n 94) 196.

${ }^{170}$ On how transparency could lead to a re-politicization of investment disputes, see Rubins (n 47) 6-8.

${ }^{171}$ See Pérez (n 94) 196 with reference to the rejection by the CJEU of the EP's proposal to make the hearings for the selection of CJEU judges open to the public. The CJEU argued that this would undermine judicial independence. 
and the outcome of the selection process with a detailed reasoning. ${ }^{172}$ If possible, a transcript of the hearings should also be included.

Concerning the $E P$ or $M E P s$, certain types of participatory transparency could be envisaged. The first type would entail (b) the granting of observer status to certain MEPs. In a way, the 2010 IA in point 26 could allow this, since it mentions the possibility of MEPs to act as observers in international bodies in which the Commission participates, without specifying the duties of such bodies. This type of participatory transparency that does not provide for the involvement of the observer in the decision-making process would result in similar levels of legitimacy as some forms of transparency in rationale. ${ }^{173}$

Nevertheless, an argument could be made that at least some members of an official body representing the general public, in this case some MEPs from the INTA Committee, (c) should be members of the selection process. Higher levels of legitimacy could be achieved since the MEPs would participate in the deliberation and not only observe. This would be the optimal solution since the participation of parliamentary bodies in the process of international judicial selection might provide checks on executives and potentially create greater democratic legitimacy, open deliberations, and transparency. ${ }^{174}$ Examples from other international adjudicative bodies seem to provide some backing to the argument that representative bodies need to play a bigger role in the selection of international judges. For example, in case of the WTO Appellate Body, the Dispute Settlement Body (DSU) appoints the members by consensus. ${ }^{175}$ This decision is taken on the recommendation of a Selection Committee, composed of the Chairs of the General Council, the DSB and other WTO councils. ${ }^{176}$ ICJ judges are elected by the Security Council and the General Assembly, the representative body, following a nomination by the national groups. ${ }^{177}$

\footnotetext{
${ }^{172}$ Concerns have also been voiced against the pubic availability of the reasons for choosing/rejecting a candidate. See Pérez (n 94) 197.

${ }^{173}$ De Fine Licht and Naurin (2011)( n 44) 21.

${ }^{174}$ Pérez (n 94) 191-192. According to Pérez this assumption is not absolute given the lack of an international demos, the possible politicization of the selection process, corroborated with the lack of adequate rules on transparency.

${ }^{175}$ Dispute Settlement Understanding (DSU), art 2.4. For the appointment of WTO panellists, see Pauwelyn 2015 (n 154) 784-786.

176 Peter van den Bossche and Werner Zdouc, The Law and Policy of the World Trade Organization (CUP, $3^{\text {rd }}$ edn 2013) 232. For a discussion on the selection of CJEU and ECtHR judges see Alberto Alemanno, 'How Transparent is Transparent Enough?' in Bobek (n 94).

${ }^{177}$ ICJ Statute, art 4. Nonetheless, the General Assembly is made up of representatives of state governments.
} 


\subsubsection{How Should the EP Do It?}

We first have to differentiate between the optimal and the acceptable solution. It would be optimal if the EP achieved the public availability of information regarding the selection process and MEPs were members of the selection process. An acceptable solution would be if information was still provided to the public, but MEPs only took part in the selection process as observers.

i. Existing FTIAs - In case of existing EU FTIAs, which have yet to be concluded, the EP would most probably be able to achieve the acceptable solution. Thus, it should insist during the ratifications that a clause be included according to which information about the nomination and appointment processes have to be made public. If the threat of a veto is not a politically viable option and the agreements come into force, the EP could still insist that under point 26 of the 2010 IA, some of its members should be granted observer status to the treaty committee meetings when the selection of the arbitrator-judges is being decided. Furthermore, the Commission via DG Trade should keep the EP informed throughout the selection process.

ii. Future FTIAs - For future EU FTIAs, the EP should aim for the optimal solution. Thus, already in the agenda phase it should insist that provisions should be included according to which a member of the INTA Committee is to take part in the Selection Committee nominating the arbitrator judges. Furthermore, mandatory provisions should be included during the negotiation process according to which the results and reasons for the appointment of the arbitrator-judges shall be made available to the general public.

\begin{tabular}{|c|c|c|c|}
\hline \multirow[t]{2}{*}{ PHASE } & \multirow[t]{2}{*}{ EP OVERSIGHT } & \multicolumn{2}{|c|}{ Selection of Arbitrator-Judges } \\
\hline & & Existing EU FTIAs & Future EU FTIAs \\
\hline \multirow{2}{*}{\multicolumn{2}{|c|}{ Proposed Changes }} & \multicolumn{2}{|c|}{$\begin{array}{l}\text { (a) Info made public (b) MEPs observe } \\
\text { (c) MEPs members of the selection process }\end{array}$} \\
\hline & & Acceptable solution: (a)+(b) & Optimal solution: $(\mathrm{a})+(\mathrm{c})$ \\
\hline \multirow[t]{2}{*}{ Agenda setting } & Formal tools & $\mathrm{X}$ & invite COM to complement ImpA \\
\hline & Informal tools & $\mathrm{X}$ & resolutions, consultations \\
\hline \multirow[t]{2}{*}{ Negotiations } & Formal tools & $\mathrm{X}$ & $\begin{array}{l}\text { right to be informed; COM reports } \\
\text { regularly }\end{array}$ \\
\hline & Informal tools & threat of veto? & $\begin{array}{l}\text { threat of veto; direct talks with foreign } \\
\text { negotiators; resolutions; working } \\
\text { groups }\end{array}$ \\
\hline \multirow[t]{2}{*}{ Ratification } & Formal tools & veto unlikely; postpone cons.? & veto, postpone consent \\
\hline & Informal tools & \multicolumn{2}{|c|}{ Consultations with COM on possible modifications? } \\
\hline \multirow[t]{2}{*}{ Implementation } & Formal tools & \multicolumn{2}{|c|}{ MEP observers under IA 2010 p 26; Obligation of COM to inform } \\
\hline & Informal tools & \multicolumn{2}{|c|}{ Consultations with COM; EPRS evaluations } \\
\hline
\end{tabular}

Fig 4 - Proposed changes for the transparency of the selection of arbitrators 


\section{Conclusions}

The EU's investment policy is continually evolving. The texts of the EU FTIAs are 'largely framed on politically-popular and/or reactive solutions, ${ }^{178}$ that might undermine attempts to design a sustainable investment regime. It is exactly for this reason that more work needs to be done now, before some of these clauses succumb to institutional 'inertia' and become 'model' clauses, 'gold standards' for future agreements. The EP has a crucial role to ensure the transparency of these agreements, especially in the current climate of waning social and public legitimacy. This article argued that the public legitimacy of these FTIAs could be bolstered if the $\mathrm{EP}$, as the only democratically elected body at an EU level, ensures enhanced transparency of the workings of various treaty committees and dispute settlement bodies set up by these agreements that deal with investment protection.

Most of the EU FTIAs have come a long way from older IIAs. Nevertheless, there is still work to be done. First, it is laudable that the transparency of the investor-state arbitral proceedings has been considerably improved. Nonetheless, reference to the UNCITRAL TR is a must, supplemented with some of the minor recommendations, such as disclosing settlement agreements and third party funding to the general public. Second, the workings of treaty committees that deal with investment protection mostly lack any specific rules on transparency, disclosure of information and public participation. In this case all the existing FTIAs are deficient and some of the changes should be pushed in the ratification phases. If this is politically not feasible, for agreements such as EU-Singapore or CETA, the EP should avail itself of various formal and informal tools in the implementation phase. Third, the selection of arbitrators/judges that will sit on future Investment Courts also has to be made more transparent, the bare minimum being the possibility of MEPs to observe the appointment process and to make public, information regarding the appointment process.

${ }^{178}$ Dickson-Smith (n 160) 809. 